\title{
НЕИЗВЕСТНЫЙ КОНТЕКСТ ЗНАМЕНИТОГО ОТКРЫТИЯ: РАБОТА М. П. ГРЯЗНОВА В ЦЕНТРАЛЬНОМ КАЗАХСТАНЕ В СОСТАВЕ ЭКСПЕДИЦИИ ПРОФЕССОРА П. С. РЫКОВА в 1933 году (к прошедшему 85-летию открытия первого памятника бегазы-дандыбаевской культуры)
}

\author{
(C) 2020 г. Н. Ю. Смирнов
}

В статье на основе документальных свидетельств реконструируется процесс открытия и исследования М. П. Грязновым первого памятника бегазы-дандыбаевской культуры - сооружения № 11 на могильнике Дандыбай в Центральном Казахстане. Впервые вводится в научный оборот целый ряд архивных документов, касающихся причин участия М. П. Грязнова в работе Нуринской экспедиции ГАИМК, условий работы самой экспедиции и первой попытки научного осмысления открытого им памятника. Иллюстрируют публикацию любительские фотографии рабочих моментов, сделанные во время раскопок одним из научных сотрудников экспедиции, и факсимиле документов, касающихся процесса работы экспедиции.

Ключевые слова: археология, М. П. Грязнов, М. Н. Комарова, Л. Р. Кызласов, А. Х. Маргулан, П. С. Рыков, бегазы-дандыбаевская археологическая культура, история археологии Казахстана, Карагандинский ИТЛ, Комитет по работам ГАИМК на новостройках, Нуринская экспедиция ГАИМК, совхоз «Гигант», Центральный Казахстан

"Погребение Дындыбай 11 раскопано мною в 1933 г. на реке Чурубай-нура примерно в 60 км к ЮЗ от г. Караганды".

М. П. Грязнов

"Значительная доля успеха в работе Экспедиции должна быть отнесена
в счет этого внимания и постоянного содействия со стороны высшей
администрации Карлаг'а и ей подчиненных работников на местах,
оказывавшегося как Экспедиции в целом, так и отдельным ее участникам".

П. С. Рыков

"Первые археологические работы в Центральном Казахстане после Великой Октябрьской сочиалистической революичи провела Нуринская экспедиция ГАИМК, организованная в 19332.

В ее составе работали известные археологи нашей страны П. С. Рыков (начальник экспедиции), М. И. Артамонов, М. П. Грязнов, Н. Арзютов, И. В. Синицыни и др.

Важным достижением экспедииии было открытие знаменитого памятника Дандыбай в долине р. Шерубай-Нура, в 60 км к юго-западу от г. Караганда».

А. Х. Маргулан

Работа выполнена в рамках программы ФНИ ГАН РФ по теме государственного задания № 0184-2019-0004 «Взаимодействие древних культур Северной Евразии и цивилизаций Востока в эпоху палеометалла (IV тыс. до н. э. - I тыс. до н. э.)». Настоящая статья планировалась к публикации еще в 2019 г. и на нее уже появились ссылки в печати [Панкратова, 2019, с. 35-36], однако, по объективным причинам, она выходит в свет только сейчас. 
Смирнов Н.Ю. Неизвестный контекст знаменитого открытия: работа М.П. Грязнова...

Введение и некоторые замечания по историографии сюжета

В 2018 г. археологическое сообщество Казахстана и России обошло вниманием одну важную дату - 85 лет со дня открытия первого памятника бегазы-дандыбаевской культуры Центрального Казахстана - одной из самых интересных культур эпохи поздней бронзы восточной части евразийских степей.

Этот памятник - сооружение № 11 могильника Дандыбай (в написании 1933 г. - Дындыбай/ Дынды-бай) - был открыт и исследован в 1933 г. в Карагандинской области Казакской АССР (до 5 февраля 1936 г. - официальное название автономной республики в составе РСФСР) на р. Шерубайнура (в написании 1933 г. - Чурубай-нура) близ аула Дандыбай (в написании 1933 г. Дындыбай/Дынды-бай) экспедицией Государственной академии истории материальной культуры Народного комиссариата просвещения РСФСР (далее - ГАИМК, академия) под руководством профессора Павла Сергеевича Рыкова (рис. 1) [Рыков, 1933; 1935; Переписка по организации работ..., л. 76]. В процессе создания и работы экспедиция получила название Нуринской по основному району исследований - бассейну р. Нуры [Рыков, 1933; Смирнов, 2020].

Непосредственным руководителем раскопок кургана № 11 был заместитель начальника экспедиции Михаил Петрович Грязнов. Вместе с ним в экспедиции работала его жена Мария Николаевна Комарова (рис. 2) [Грязнов, 1952, с. 130; Переписка по организации работ..., л. 58].

Краткая информация о ходе работ и результатах полевых исследо- ваний Нуринской экспедиции была опубликована в одном из изданий ГАИМК в год ее проведения. Позднее начальник экспедиции, профессор П. С. Рыков, поместил развернутую статью об открытых памятниках (по сути, это был отредактированный для печати полевой отчет) в специальном томе Известий ГАИМК (рис. 3), посвященном работе академии на новостройках [Рыков, 1933, с. 57-58; 1935, c. 40-68].

В самом начале 1950-х гг. была опубликована программная статья М. П. Грязнова, в которой он обосновывал свою интерпретацию погребения в кургане № 11 могильника Дандыбай и на новом уровне анализировал находки из этого комплекса [Грязнов, 1952]. Нетрудно заметить, что от момента раскопок (1933 г.) до

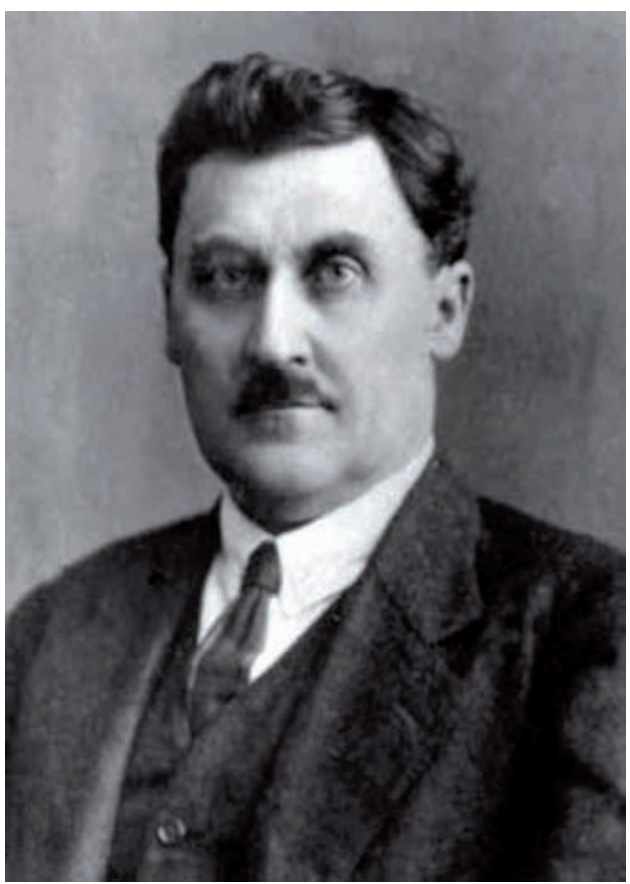

Рис. 1. П.С. Рыков. Фото. 1930-е г2. (nо: [Кафедра истории России...])

Fig. 1. P. S. Rykov. Photo. 1930s (after: [In Saratov State University])) 


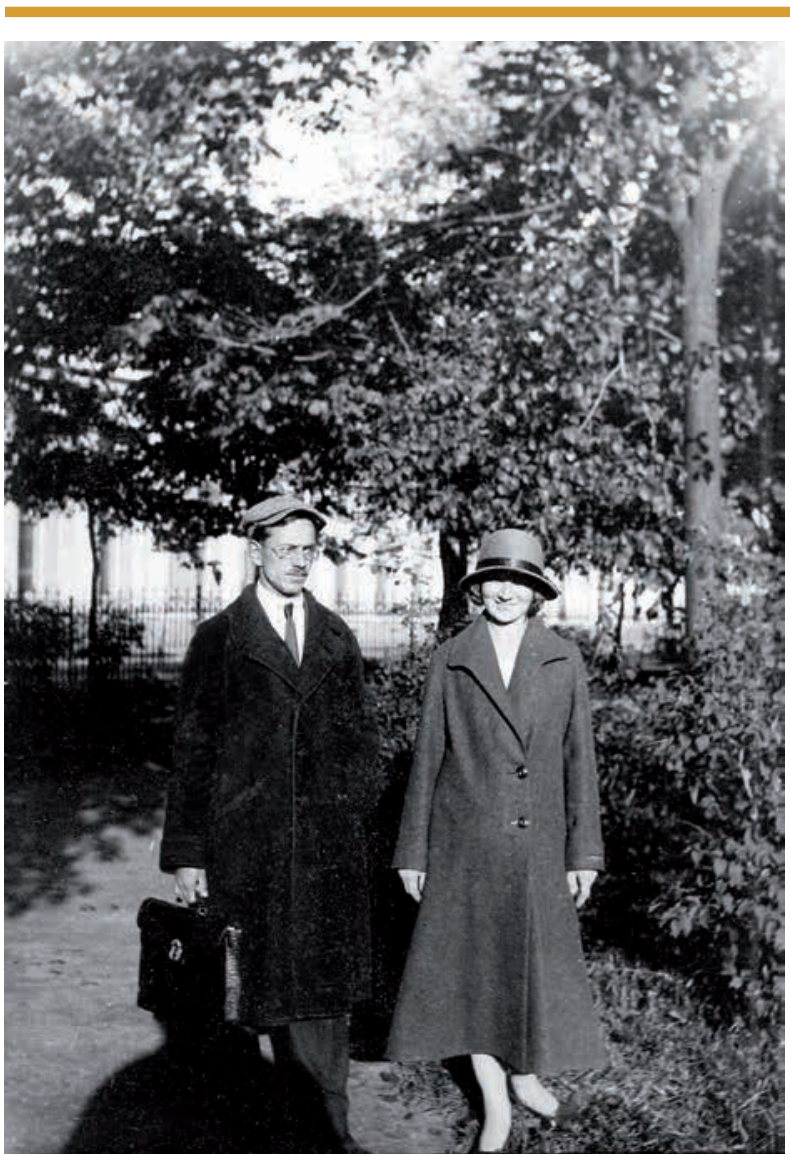

Рис. 2. М.П. Грязнов и М.Н. Комарова. Фото. Вторая половина 1920-х г2. (nо: [Бытовые фотографии родныхх и знакомыхх..., л. 36])

Fig. 2. M. P. Gryaznov and M. N. Komarova. Photo. Second half of the 1920 s (after: [In NA IIMK RAN, sheet 36])

затрагивающую материалы из раскопок М. П. Грязнова в 1933 г. [Кызласов, Маргулан, 1950]. В процессе пятилетних (1947-1952 гг.) исследований А. Х. Маргулана на могильнике Бегазы его экспедицией был изучен ряд объектов, материал которых находился «в русле культурных особенностей кургана № 11 могильника Дандыбай» [Бейсенов и др., 2014, c. 10].

В 1947 г. А. Х. Маргулан, открывший могильник Бегазы годом ранее, раскопал одну малую плиточную ограду № 4 [Mаргулан, 1949/1950, с. 13-18; Кызласов, Маргулан, 1950, c. 126]. В следующем, 1948 г., в раскопках могильника Бегазы принял участие 24-летний студентстаршекурсник исторического факультета МГУ Л. Р. Кызласов, исследовавший одну большую (№ 2) и еще одну малую (№ 3) ограды [Кызласов, Маргулан, 1950 , с. 126; Кызла-

авторской публикации (1952 г.) прошло почти 20 лет. К обсуждению причин этой странной паузы я обращусь позднее.

Несомненно, что вышедшая в 1952 г. работа, в которой были заново и в лучшем полиграфическом качестве представлены находки из кургана № 11 могильника Дандыбай, дополненная обширной аналитической частью, явилась своего рода критическим откликом на напечатанную двумя годами ранее статью Л. Р. Кызласова и А. Х. Маргулана, напрямую сов И., 2017, с. 16; Кызласов Л., 2017 , с. 72]. В 1950 г. вышла совместная статья А. Х. Маргулана и Л. Р. Кызласова, уже аспиранта МГУ, подводившая некоторые итоги работ 1947-1948 гг., и целиком посвященная интерпретации трех раскопанных соавторами объектов [Кызласов, Маргулан, 1950].

$$
\text { В публикации } 1952 \text { г. }
$$

М. П. Грязнов отстаивал идею о принадлежности сооружений с оградами и схожей керамикой из могильников Дандыбай и Бегазы кругу памятников карасукской культурной традиции, 
Смирнов Н.Ю. Неизвестный контекст знаменитого открытия: работа М.П. Грязнова...

соответственно датируя их эпохой поздней бронзы [Грязнов, 1952, с. 130 и далее], а Л. Р. Кызласов и А. Х. Маргулан, в своей статье, относили раскопанные ими объекты к кругу памятников традиции плиточных могил Монголии и Забайкалья, включая туда и курган № 11 могильника Дандыбай, и датировали этот пласт древностей «раннескифским» временем - VIIVI вв. до н. э. [Кызласов, Маргулан, 1950, с. 136].

Слегка отклоняясь от основной темы статьи, хочу указать на несколько забавных историографических аберраций, возникших в относительно недавних работах, касающихся истории изучения бегазы-дандыбаевской культуры и конкретно разбираемого сюжета. Так, одну из них можно обнаружить в заметке С. С. Тихонова, который пишет о «раскопках А. Х. Маргулана (1947) и Л.Р. Кызласова (1948) на памятнике Бегазы и их совместной статье», вышедшей в 1950 г. [Тихонов, 2009, с. 192]. Вследствие такого описания создается впечатление, что А. Х. Маргулан и Л. Р. Кызласов, каждый в течение одного года, независимо друг от друга (и, видимо, сменяя друг друга), копали один и тот же могильник. Однако это не так. А. Х. Маргулан руководил работами Центрально-Казахстанской экспедиции на могильнике Бегазы с 1947 по 1952 г., а Л. Р. Кызласов в 1948 г. был участником этой экспедиции и начальником отряда [Бейсенов и др., 2014, с. 10; Кызласов И., 2017; Кызласов Л., 2017, с. 71]. Реальность состоит в том, что каждый из них (и начальник экспедиции, и сотрудник экспедиции) самостоятельно

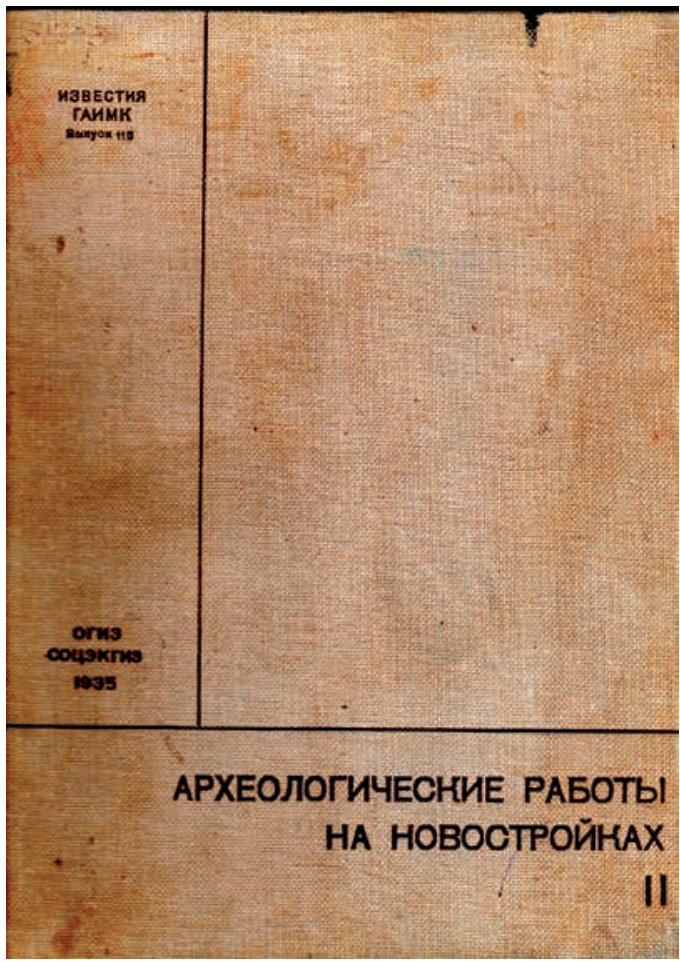

Рис. 3. Обложка тома II сборника трудов ГАИМК «Археологические работь Академии на новостройках в 1932-33 г2.» (ИГАИМК, вbln. 110),

в которой были опубликованы материаль Нуринской экспедиции [по: Рыков, 1935]

Fig. 3. Cover of volume II of the collection of works of GAIMK "Археологические работы Академии на новостройках в 1932-33 г2." (Archaeological works of the Academy at construction sites in 1932-33) (ИГАИМК, issue 110) where the materials of the Nura expedition were published (after: [Rykov, 1935])

руководил раскопками тех объектов, которые вкупе рассматриваются в совместной статье 1950 г. [Кызласов, Маргулан, 1950, с. 126]. Повторяется та же аберрация и в другой работе С. С. Тихонова, где он пишет уже о том, что в послевоенные годы «инициатива... в изучении бронзового века Казахстана переходит (от М. П. Грязнова - Н.С.) к молодым ученым (тогда, в далекие послевоенные годы, молодым) Л. Р. Кызласову и А. Х. Маргулану, раскопавшими 
(sic!) в 1947 и в 1948 гг. могильник Бегазы и впоследствии опубликовавшими (sic!) его материалы...» [Тихонов, 2010, с. 32]. Здесь дело не только в том, что повторяется крайне неудачно сформулированная мысль и, тем самым, закрепляется в голове читателя неверное восприятие истории изучения памятника, но и в том, что само высказывание теперь дополняет оксюморон. В действительности, после войны «молодым ученым» можно было назвать только Л. Р. Кызласова (см. выше), а А. Х. Маргулан, родившийся в 1904 г., был практически сверстником М. П. Грязнова, родившегося в 1902 г! Успешное обращение А. Х. Маргулана к изучению бронзового века Казахстана никак невозможно объяснить его «молодостью», но лишь тем, что он в послевоенные годы достаточно быстро стал признанным лидером казахстанского археологического сообщества, а также его специфическим полевым везением. О последнем красочно написал в своих воспоминаниях Л. Р. Кызласов, образно назвав это «парадоксом Маргулана» [Кызласов Л., 2017, с. 72].

Еще одна аберрация - упоминание в первой главе обобщающего труда, подводящего итоги нового периода изучения бегазы-дандыбаевской культуры, о том, что «в 1948 г. в раскопках (могильника Бегазы - Н.C.) принял участие профессор МГУ Леонид Романович Кызласов...» [Бейсенов и др., 2014, с. 10]. Это звучит красиво, но неминуемо вводит читателя в заблуждение. Сопоставление даты рождения Л. Р. Кызласова, а также основных вех его биографии с датами раскопок могильника Бегазы недвусмысленно демонстрирует то, что в 1948 г. в Центральный Казахстан приехал 24-летний студент старших кур- сов университета [Кызласов И., 2017, c. 16], а никак не профессор, звание которого Л. Р. Кызласов получит только через 20 лет.

Возвращаясь к истории открытия и исследования сооружения № 11 могильника Дандыбай, отмечу, что позднее, после выхода статьи М. П. Грязнова, к материалам памятника неоднократно обращались исследователи бегазы-дандыбаевских древностей Центрального Казахстана. Однако в их работах история изучения кургана № 11 не становилась предметом специального исследования (в качестве примера приведу только обобщающие монографии: [Маргулан, 1979, с. 11, 147-153; Бейсенов и др., 2014, с. 9-10, 76-79]).

Ситуация начала меняться около 10 лет назад. В 2009 г. вышла короткая, но очень важная в свете настоящей темы статья (по своей форме и характеру это, скорее, заметка) омского археолога и историка науки C. С. Тихонова, на страницах которой он, к сожалению, весьма отрывочно и конспективно изложил свое видение истории организации и работ Нуринской экспедиции ГАИМК, опираясь на ранее неизвестные материалы из омской части личного архива М. П. Грязнова, опубликованные работы П. С. Рыкова, М. П. Грязнова, А. Х. Маргулана и Л. Р. Кызласова, а также на данные открытых источников [Тихонов, 2009]. Отдельные, отраженные в заметке 2009 г., наблюдения и выводы повторяются в более поздней работе С. С. Тихонова, но также, большей частью, без опоры на документальные свидетельства [Тихонов, 2010, с. 29-30].

Мне представляется наиболее важным то, что в этих двух текстах С. С. Тихонов впервые в печати вы- 
Смирнов Н.Ю. Неизвестный контекст знаменитого открытия: работа М.П. Грязнова...

сказал мнение о том, что экспедиция профессора П. С. Рыкова в 1933 г. работала на территориях, подведомственных ГУЛАГу - в зоне Карагандинского ИТЛ (далее - Карагандинский ИТЛ, Карлаг) и подкрепил это рядом соображений [Тихонов, 2009, c. $188 ; 2010$, с. 30$]$.

Рассматривая эти работы С. С. Тихонова как первую осознанную попытку разобраться в истории Нуринской экспедиции 1933 г. и, в целом, отдавая должное интуиции автора, позволившей ему верно обозначить канву сюжета, связанного с организацией одной из любопытнейших новостроечных экспедиций ГАИМК, я с сожалением вынужден отметить, что общее впечатление от них портят досадные для историка науки, имеющего значительный опыт работы с архивным материалом и хорошо знакомого с документами личного архива М. П. Грязнова (омская часть), ошибки, а также несколько поверхностные трактовки и неудачные формулировки.

Например, безусловным анахронизмом является вынесенное в заголовок более ранней заметки и упоминаемое в первом абзаце текста и далее название научной организации, командировавшей экспедицию «Институт истории материальной культуры»/«ИИМК» [Тихонов, 2009, c. 187]. Общеизвестный факт состоит в том, что до 1937 г. учреждение являлось не институтом, а академией и официально называлось (с 1926 г.) Государственная академия истории материальной культуры (ГАИМК). Более того, упомянутая в статье «Академия наук» (видимо, СССР?) не могла никого из археологов никуда отправить, вопреки утверждению автора [Тихонов, 2009, с. 188], так как до 1937 г. не имела отношения к ГАИМК, входившей в систему Народного комиссариата просвещения РСФСР. Подобные ошибки тем более странны, в виду того, что в том же тексте С. С. Тихонов неоднократно ссылается на издания ГАИМК!

Точно таким же анахронизмом является упоминание в заметках, посвященных работе экспедиции 1933 г., Народного комиссариата внутренних дел (НКВД), видимо, РСФСР (?), в контексте деятельности ГУЛАГа [Тихонов, 2009, с. 188-189; 2010, с. 30]. Дело в том, что в 1933 г. Главное управление лагерей относилось к ведомству Объединенного государственного политического управления (ОГПУ), подчиняющемуся непосредственно Совнаркому, а вовсе не к НКВД РСФСР, упраздненному в 1930 г., или НКВД СССР, созданному 10 июля 1934 г.

Трудно сдержать удивление, читая фразу о том, что по своему характеру «состав экспедиции сборный, т. е. набрали кого смогли и послали куда надо» [Тихонов, 2009, с. 187]. Безусловно, состав экспедиции был сборным, но неслучайным: в него входил опытный начальник - организатор крупных полевых археологических работ и вполне советски настроенный, что было особенно важно в этом случае, П. С. Рыков [Худяков, 1935, с. 155-156; Максимов, 1989 , с. 11 ; Малов, 2006, с. 20 21], два его ближайших ученика, проводившие самостоятельные полевые исследования, - И. В. Синицын [К 70-летию..., 1972, с. 6; Каргин, 2010, с. 7-8] и Н. К. Арзютов [Максимов, 1998, с. 194-195], а также М. И. Артамонов, М. П. Грязнов и М. Н. Комарова - молодые кадры ленинградских учреждений, уже имев- 
шие неплохой полевой опыт и, что важно, различную археологическую специализацию. Новичком из всего состава был аспирант ГАИМК, будущий палеолитчик и исследователь Костёнок А. Н. Рогачев. При этом П. С. Рыков и М. П. Грязнов имели опыт работы в казахских степях, что отмечает и сам С. С. Тихонов [Тихонов, 2009, с. 187].

Не менее странными выглядят предположения автора о «предупредительности» и «внимании» администрации Карлага по отношению к участникам археологической экспедиции, проявляемым по некоей «обязанности» [Тихонов, 2009, с. 189]. Обязанность была одна: строгий контроль всего, что происходит на территории лагеря. Внимание и предупредительность администрации Карлага были обусловлены сопроводительными документами экспедиции - «верительными грамотами», заблаговременно полученными ее начальником в ГУЛАГ ОГПУ в Москве [Смирнов, 2020].

Причины и история создания Нуринской экспедиции ГАИМК подробно разобраны мной в отдельной работе [Смирнов, 2020]. Там же даны отсылки к большинству архивных источников, документирующих процесс организации экспедиции, знание которых необходимо и для адекватной реконструкции сюжета, рассматриваемого в настоящей статье. Дабы избежать повторов, перечислю ниже лишь ключевые факторы, несомненно, влиявшие на участников Нуринской экспедиции ГАИМК, отослав заинтересованного читателя за расширенным комментарием к другой своей работе [Смирнов, 2020].

Организащия экспедищуии

Нуринская экспедиция ГАИМК была создана в 1933 г. для исполне- ния договора между академией и ГУЛАГ ОГПУ об организации спасательных археологических работ (разведки и раскопки) на территории «совхоза "Гигант"» - Карагандинского ИТЛ. Договор был заключен в результате активной деятельности ГАИМК по привлечению средств государственных организаций к осуществлению спасательных археологических исследований в зонах нового крупного строительства СССР. Полевые работы Нуринской экспедиции 1933 г. были связаны с изучением археологических памятников, которым угрожало уничтожение в результате активной хозяйственной деятельности, нацеленной на создание обширных сельскохозяйственных угодий Карлага. Это была новостроечная, в современном понимании, спасательная археологическая экспедиция с жестким графиком работ и регулярной отчетностью перед Комитетом по новостройкам ГАИМК и заказчиком работ - ГУЛАГ ОГПУ.

Экспедиция работала под руководством профессора П. С. Рыкова и при участии целого ряда молодых советских археологов - М. П. Грязнова, М. Н. Комаровой, М. И. Артамонова, И. В. Синицына, Н. К. Арзютова и А. Н. Рогачёва [Рыков, 1935; Тихонов, 2009; Смирнов, 2020].

Приведу короткий, но необходимый обзор архивных фондов, в которых содержатся документы, связанные с пребыванием М. П. Грязнова в составе Нуринской экспедиции.

Сводные полевые отчеты экспедиции (рукописный и машинописный варианты), полевые дневники участников, административная переписка, касающаяся процесса организации экспедиции, полевые фотографические материалы отложились в 
Смирнов Н.Ю. Неизвестный контекст знаменитого открытия: работа М.П. Грязнова...

Рукописном и Фото отделах Научного архива (далее - НА ИИМК РАН. РО., ФО.) Института истории материальной культуры Российской академии наук (далее - ИИМК РАН) - прямого наследника ГАИМК [Переписка Комитета новостроек...., Переписка по организации работ..., Отчеты и переписка о раскопках..., Материалы Нуринской экспедиции..., И. В. Синицын. Черновые дневниковые заметки... и ряд других; Нуринская экспедиция ГАИМК...].

Полевая и отчетная документация, которую вел М. П. Грязнов как заместитель начальника экспедиции, сохранилась в его личном архиве, но после его смерти, к сожалению, оказалась разрознена в связи с имевшим место искусственным расчленением архива на ленинградскую (санктпетербургскую) и омскую части. Основной объем документов из личного архива М. П. Грязнова остался в Ленинграде (Санкт-Петербурге) и поступил на хранение в НА ИИМК РАН. В этом фонде содержатся и документы по Нуринской экспедиции (маршрутные листы разведок, выкопировки из топографических планов, таблицы с определениями костей человека и животных и полевые заметки о раскопках погребения 11 могильника Дандыбай и других объектов) [Дандыбай 11 - памятник карасукской культуры..., л. 57-106]. Меньшая часть архива, в составе которой также имеются касающиеся настоящей темы материалы, попала в Омск, где сохранилась в фондах Музея археологии и этнографии Омского государственного университета [Тихонов, 2009, с. 187, 189, рис. 1, 2].

Некоторые документы из омской части архива М. П. Грязнова, связанные с раскопками 1933 г., были опубликованы в одном из сборников материалов конференции «Маргулановские чтения» [Тихонов, 2009] и анализировались там в связи с изложением истории раскопок могильника Дандыбай. К сожалению, из текста С. С. Тихонова невозможно понять в целом характер и объем документов, касающихся экспедиции 1933 г. в Центральный Казахстан, которые после смерти М. П. Грязнова попали в ту часть архива, что В. И. Матющенко вывез в Омск. Из приведенных в заметке иллюстраций ясно только, что речь идет, как минимум, о топографических картах с привязками памятников к местности, отдельных полевых (?) чертежах, рисунках и фотографиях вещей. Являются ли карты и чертежи копиями или оригиналами полевой документации, либо это варианты иллюстраций к будущей статье - в большинстве случаев понять из заметки также нельзя.

Принципиально новые данные, проливающие свет на историю организации экспедиции профессора П. С. Рыкова в Центральный Казахстан и особенности ее работы мне удалось выявить в последние годы еще в одном архивном фонде - в Санкт-Петербургском филиале Архива РАН (далее - СПбФ АРАН). Они содержались в фонде Секретной части АН СССР, куда в 1920-1930-е гг. передавались документы, связанные со служебной перепиской академических учреждений с советскими и партийными органами, не подлежавшие оглашению и длительное время бывшие засекреченными. Вероятно, секретная переписка ГАИМК попала в этот фонд случайно, вследствие архивных пертурбаций конца 1930 -х или начала 1990-х гг. Здесь сохранились докладная записка П. С. Рыкова 
начальнику Карлага М. М. Чунтонову о результатах работы экспедиции, приказ по лагерю о необходимости охраны археологических памятников и статья о значении археологических исследований, опубликованная во внутренней газете Карлага [Докладная записка..., л. 49-53].

Наконец, необходимая информация об административном подчинении, условиях функционирования и обитателях так называемого «совхоза "Гигант"» - Крагандинского ИТЛ, на территории которого работала в 1933 г. экспедиция профессора П. С. Рыкова, содержится в соответствующих делах фонда ГУЛАГа в Государственном архиве Российской Федерации (далее - ГА РФ) [Переписка с правительственными организациями..., л. 12-13; Сводный квартальный обзор..., л. 146, 159; и ряд других дел].

Следует отметить, что С. С. Тихонов совершенно верно сопоставил место работ экспедиции П. С. Рыкова с территорией Карагандинского ИТЛ [Тихонов, 2009, с. 188; 2010, с. 30], однако, необходимо уточнить приведенные им сведения по истории Карлага. К моменту начала работы экспедиции Карлаг уже существовал и несколько лет функционировал в виде крупнейшего производственного ИТЛ - «совхоза "Гигант"». Приказ об организации Карлага относится к осени 1931 г. [Система..., 1998. Карагандинский ИТЛ]. Первые же работы по созданию производственного хозяйства (продовольственной базы), где должны были трудиться, в основном, раскулаченные крестьянепереселенцы относятся к еще более раннему времени - 1930 г. [Система..., 1998. Казакстанский ИТЛ].

Освоение рудной базы и угольных копей Карагандинского района силами советских заключенных не только требовало прокладки отсутствовавших в регионе железных дорог, организации добычи угля и полезных ископаемых, строительства жилищ, но порождало насущную необходимость в постоянном хозяйстве [Переписка с правительственными организациями..., л. 12-13; Сводный квартальный обзор..., л. 159], которое могло бы прокормить растущие промышленные центры, да и сам этот остров ГУЛАГа, материализовавшийся среди безбрежных просторов полупустынь Центрального Казахстана.

В год работы Нуринской экспедиции численность граждан Советского Союза, высланных «на переделку» в Карлаг выросла более чем в два раза, почти достигнув отметки в 25000 человек [Сводный квартальный обзор..., л. 146; Система... 1998. Карагандинский ИТЛ].

Именно в эту зону Центрального Казахстана, где степной ландшафт теперь лишь изредка прерывался лагерными бараками, занявшими территории бывших немецких колоний, а в хозяйстве применялся почти исключительно труд заключенных, и отправился в составе других членов экспедиции тридцатиоднолетний Михаил Петрович Грязнов в надежде открыть неизвестные ранее археологические памятники.

Прекрасно понимая те условия, в которых будет работать экспедиция, руководство ГАИМК добилось не только финансирования всего цикла научно-исследовательских работ, но и соответствующего материального снабжения для сотрудников экспедиции. Полевое обеспечение (речь, конечно, идет, прежде всего, об условиях проживания, питания и об обмундировании) должно было 
Смирнов Н.Ю. Неизвестный контекст знаменитого открытия: работа М.П. Грязнова...

быть приравнено к тому, которое получали вольнонаемные работникиспециалисты, трудившиеся в лагере. По всей вероятности, статус «вольнонаемных» в отношении участников Нуринской экспедиции впоследствии был зафиксирован и юридически, хотя прямых доказательств этому нет. Я могу опираться только на письмо М. П. Грязнова в Комитет по новостройкам ГАИМК, отправленное из экспедиции, в котором он просит при переводе аванса указывать, что деньги предназначены «вольнонаемному М. П. Грязнову» [Переписка по организации работ..., л. 33, 66; Смирнов, 2020].

С договором о работах на территории «совхоза “Гигант”» был напрямую связан еще один небольшой, но очень показательный совместный проект ГАИМК и ГУЛАГа - «составление и издание инструкции по учету и охране памятников древности», которая была заказана последним у Комитета по новостройкам академии (рис. 4). Парадоксально, но даже такое чисто служебное и, казалось бы, предназначенное для решения частных задач спасательной археологии издание, - брошюра «Инструкция по учету и охране памятников материальной культуры на новостройках», вышедшая из-под пера М. И. Артамонова, М. П. Грязнова и Б. А. Латынина в 1933 г. [Артамонов и др., 1933] и претерпевшая в последствии несколько переизданий, - появилось на свет в процессе сотрудничества именно с ГУЛАГом. При этом необходимость создания таких инструкций обсуждалась еще на заседаниях Комитета по новостройкам как минимум с конца 1932 г. [Протоколы бюро Комитета..., л. 9]. Впрочем, этот сюжет достоин отдельного изучения.
5 мая 1933 г. действительный член ГАИМК и профессор Саратовского университета П. С. Рыков был назначен начальником экспедиции в «совхоз "Гигант"». Кроме того, на него были возложены обязанности ведения переговоров с ГУЛАГом относительно связанных с экспедицией организационных забот [Переписка по организации работ..., л. 55, 91; Смирнов, 2020].

В те же дни определился и окончательный состав Нуринской экспедиции (рис. 5). Список, составленный ученым секретарем Комитета по новостройкам Б. А. Латыниным, включал: Павла Сергеевича Рыкова - начальника экспедиции, Михаила Петровича Грязнова - заместителя начальника экспедиции, Михаила Илларионовича Артамонова, Ивана Васильевича Синицына и Николая Константиновича Арзютова - старших научных сотрудников, Марию Николаевну Комарову - младшего научного сотрудника и Александра Николаевича Рогачёва - научно-технического сотрудника [Переписка по организации работ..., л. 58, 101-103 об.].

А. Н. Рогачёв, как аспирант, был взят на самую низкую ставку. Сделать его техническим сотрудником было невозможно, так как по условиям договора с ГУЛАГом на довольствие специалистов ставились только научные сотрудники, с другой стороны, в официальную смету еще одна ставка научного сотрудника явно не помещалась - штаты и так были раздуты практически вдвое от первоначально запланированных, а сумма ассигнований не увеличилась. Однако, руководство не хотело обижать самого младшего участника экспедиции и ему планировалось выделить надбавку в 232 р. в счет общего ассигнования, получаемого от ГУЛАГа, 


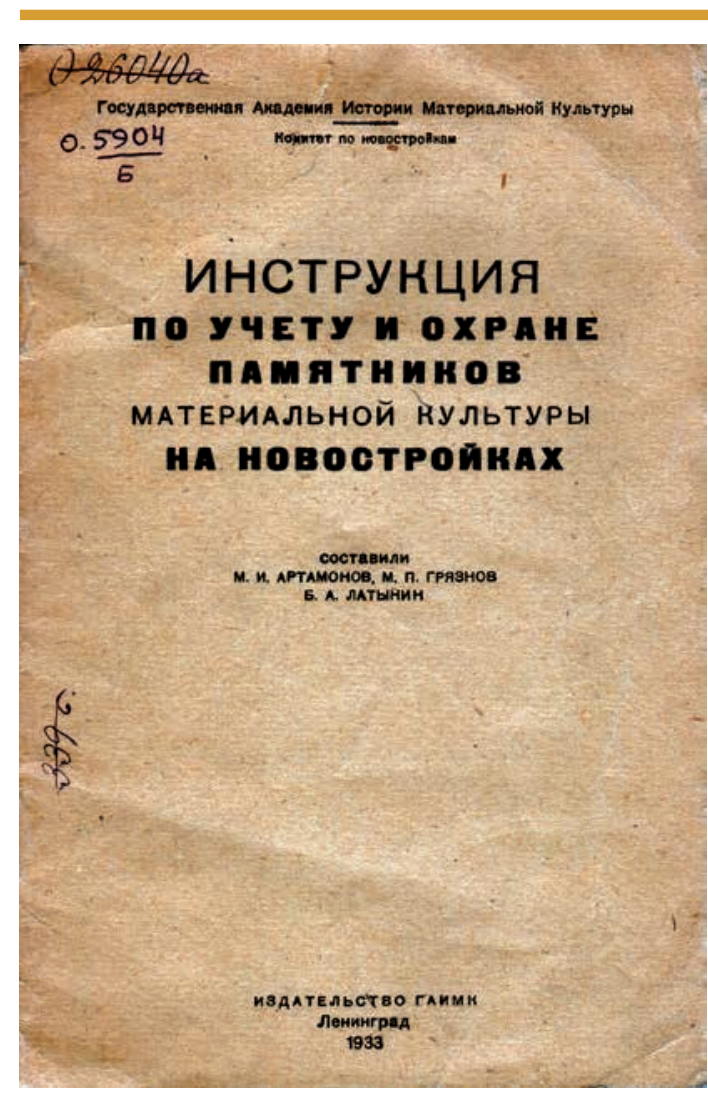

Рис. 4. Обложка «Инструкиии по учету и охране памятников на новостройках», составленной М.И. Артамоновым, М.П. Грязновым и Б.А. Латынинылм по заказу ГУЛАГ ОГПУ [по: Артамонов и др., 1933]

Fig. 4. Cover of "Инструкиии по учету и охране памятников на новостройках" (Instructions on the accounting and protection of sites at construction works) wrote by M. I. Artamonov, M. P. Gryaznov and

B. A. Latynin at the order of GULAG OGPU (after: [Artamonov et al, 1933])

для того, чтобы «доплатить разницу зарплаты до н[аучного] с[отрудника]» [Переписка по организации работ..., л. 101]. Впрочем, было ли это сделано не ясно.

М. П. Грязнов, к моменту своего зачисления в состав Нуринской экспедиции, работал в двух учреждениях: заведующим разрядом антропологии во II Технологическом отделении ГАИМК и старшим научным сотрудником Этнографического отдела Русского музея. При этом основным местом его службы был Русский музей [Академическая археология..., 2013, с. 111, 113, 117, 379]. М. Н. Комарова, жена М. П. Грязнова, в эти годы состояла техническим руководителем лаборатории механического анализа в составе Лаборатории химического анализа в Северо-Западном геологоразведочном тресте. По основному месту работы каждого ГАИМК отправила просьбы об откомандировании их в состав казахстанской экспедиции. Примечательно, что в случае с Русским музеем академия пообещала заведующему Этнографическим отделением «преимущественное право» на получение коллекций, «добытых экспедицией». А в обращении к директору Химической лаборатории было просто указано, что целью откомандирования является «включение ее (М. Н. Комаровой - Н.C.) в число сотрудников экспедиции в Центральный Казахстан, организуемой Академией по заданию Главного Управления Лагерями ОГПУ» [Переписка по организации работ..., л. 59, 60]. Как тут можно было отказать?

К 1933 г. М. П. Грязнов был уже сложившимся специалистом с широким научным кругозором и собственными теоретическими и методическими наработками, вел полевые исследования на Алтае и в Приобье, участвовал в экспедициях в Казахстане и Киргизии. М. Н. Комарова также имела хорошую полевую подготовку, работая с мужем и С. И. Руденко на Алтае.

Несомненно, что в состав экспедиции и на должность заместителя начальника М. П. Грязнов попал неслучайно. Во-первых, начальник экс- 


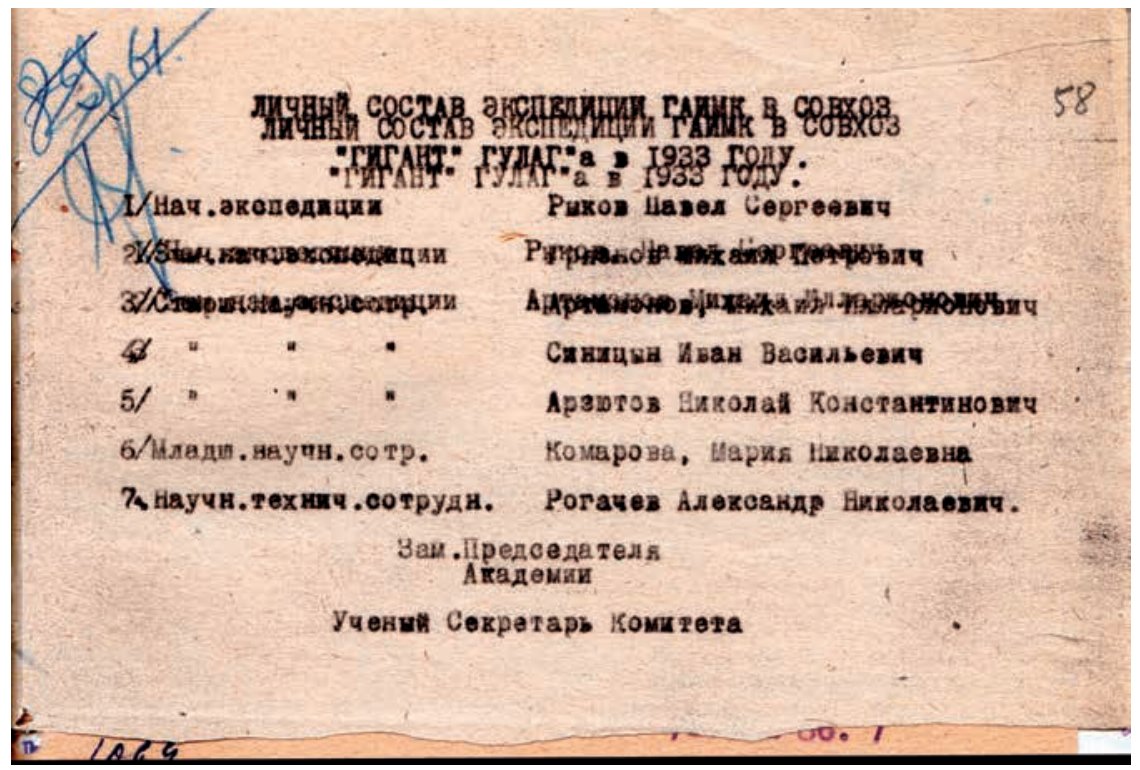

Рис. 5. Копия списка участников Нуринской экспедиции ГАИМК в совхоз ГУЛАГа «Гигант». Публикуется впервые (по: [Переписка по организаџии работ..., л. 58])

Fig. 5. Copy of the list of participants of the Nura expedition of GAIMK at the GULAG's Sovkhos 'Gigant'. First publication (after: [In NA IIMK RAN, sheet 58])

педиции, П. С. Рыков, был с ним знаком, как минимум по переписке, еще с 1927 г. [Рыков Павел Сергеевич..., л. 5-5 об.]; во-вторых, у М. П. Грязнова был уже значительный опыт ведения самостоятельных полевых работ. Думаю, что не последнюю роль сыграли также и личностные качества М. П. Грязнова. Показательно, что на его имя академией были выданы авансовые денежные средства, а затем П. С. Рыков поручил ему ведение всех финансовых дел экспедиции [Переписка по организации работ..., л. 82 об].

Впрочем, у меня есть и еще одно предположение объяснительного характера. Вероятно, в этот период М. П. Грязнов находился на научном перепутье: совместные работы с С. И. Руденко на Первом Пазырыкском кургане его явно разочаровали, а после ареста последнего продолжение таких затратных исследований и вовсе стало невозможным. Тем временем, в круг интересов молодого ученого попадают Казахстан и Средняя Азия. С начала 1930-х гг. именно там разворачиваются гигантские стройки социализма, которые вместе с угрозой уничтожения памятников археологии приносят и деньги на их раскопки, а соответственно, возможность заниматься научными исследованиями. Трудно сказать, что здесь преобладало: собственный научный интерес М. П. Грязнова или веяние времени, а, возможно, и желание руководства ГАИМК подключить своего, ленинградского, специалиста, к ответственному направлению работ, переориентировав его на Казахстан, но все очевидные векторы интересов явно совпали.

После успешных переговоров П. С. Рыкова с представителями ГУЛАГа в Москве, состоявшихся в начале мая 1933 г., М. П. Грязнов ак- 
тивно включился в работу по подготовке экспедиции.

2 мая 1933 г. ГАИМК послала письмо в Наркомпрос с просьбой выдать Открытые листы на имя начальника экспедиции, его заместителя и троих старших научных сотрудников [Переписка Комитета новостроек..., л. 192]. Уже через две недели, 15 мая 1933 г., Открытые листы «на раскопки в совхозе "Гигант" в Казахстане (район Караганды и р[еки] Нура)» (рис. 6) были выданы [Отчеты и переписка о раскопках..., л. 1].

В последней декаде мая П. С. Рыков находился дома, в Саратове, по всей видимости, занимаясь сборами. Оттуда 21 мая он отправил М. П. Грязнову пространное письмо, в котором излагал свои мысли относительно дня встречи членов экспедиции в Москве и предлагал согласовать сроки выезда, а также просил того напомнить Б. А. Латынину о денежном переводе и захватить с собой аптечку [Рыков Павел Сергеевич..., л. 1-1 об.]. Эта любопытная деталь свидетельствует о специфических условиях социалистической экономики начала 1930-х гг., при которых экспедиционную аптечку удобнее было собрать в Ленинграде, чем в Саратове. Не исключено, что ГАИМК могла позволить себе комплектовать такие аптечки из средств своего бюджета.

В конце мая - начале июня, пока решался вопрос о дате выезда, переводились авансы, бронировались места для проезда в поезде из Москвы до Караганды и совершались последние приготовления в Саратове и Ленинграде, П. С. Рыков снова приехал в Москву, чтобы закончить переговоры с ГУЛАГ ОГПУ, оформить командировку и получить карту района будущих работ. За это время в адрес
М. П. Грязнова ушло несколько телеграмм, в которых обсуждались насущные проблемы: получение денег, место сбора экспедиции в Москве и дата отъезда. Не обошлось без накладок - из-за отсутствия билетов на поезд экспедиция застряла на несколько дней в Москве и выехала в Караганду только 7 июня [Смирнов, 2020].

К счастью, существует своеобразная летопись Нуринской экспедиции ГАИМК, которая писалась ее начальником и его заместителем П. С. Рыковым и М. П. Грязновым. Сначала в письмах, отправляемых каждые 10 дней из экспедиции в Ленинград, в адрес Комитета по новостройкам ГАИМК, а затем в виде обобщающих докладов начальника экспедиции руководству Комитета и начальнику Карлага, были изложены основные события полевой жизни [Переписка по организации работ..., л. 65-67, 70-70 об., 72-76, 78-82; Докладная записка начальника..., л. 5153]. Эти документы расцвечивают сухие строки полевого отчета [Mатериалы Нуринской экспедиции...; Отчеты и переписка о раскопках...] и опубликованных на его основе заметки и статьи [Рыков, 1933; 1935].

Всего из экспедиции в Ленинград было отправлено семь рукописных писем, частью за подписями П. С. Рыкова и М. П. Грязнова, а частью за подписью одного М. П. Грязнова. Кроме них было составлено и, видимо, отправлено вместе с письмами или параллельно им, четыре «акта»: о «прибытии экспедиции к месту работ», о проведенных за определенный период работах, «об окончании полевых работ» и о выполнении всех полевых работ, упомянутых в договоре с ГУЛАГом [Переписка по организации работ..., л. 73-75, 78]. 
Смирнов Н.Ю. Неизвестный контекст знаменитого открытия: работа М.П. Грязнова...

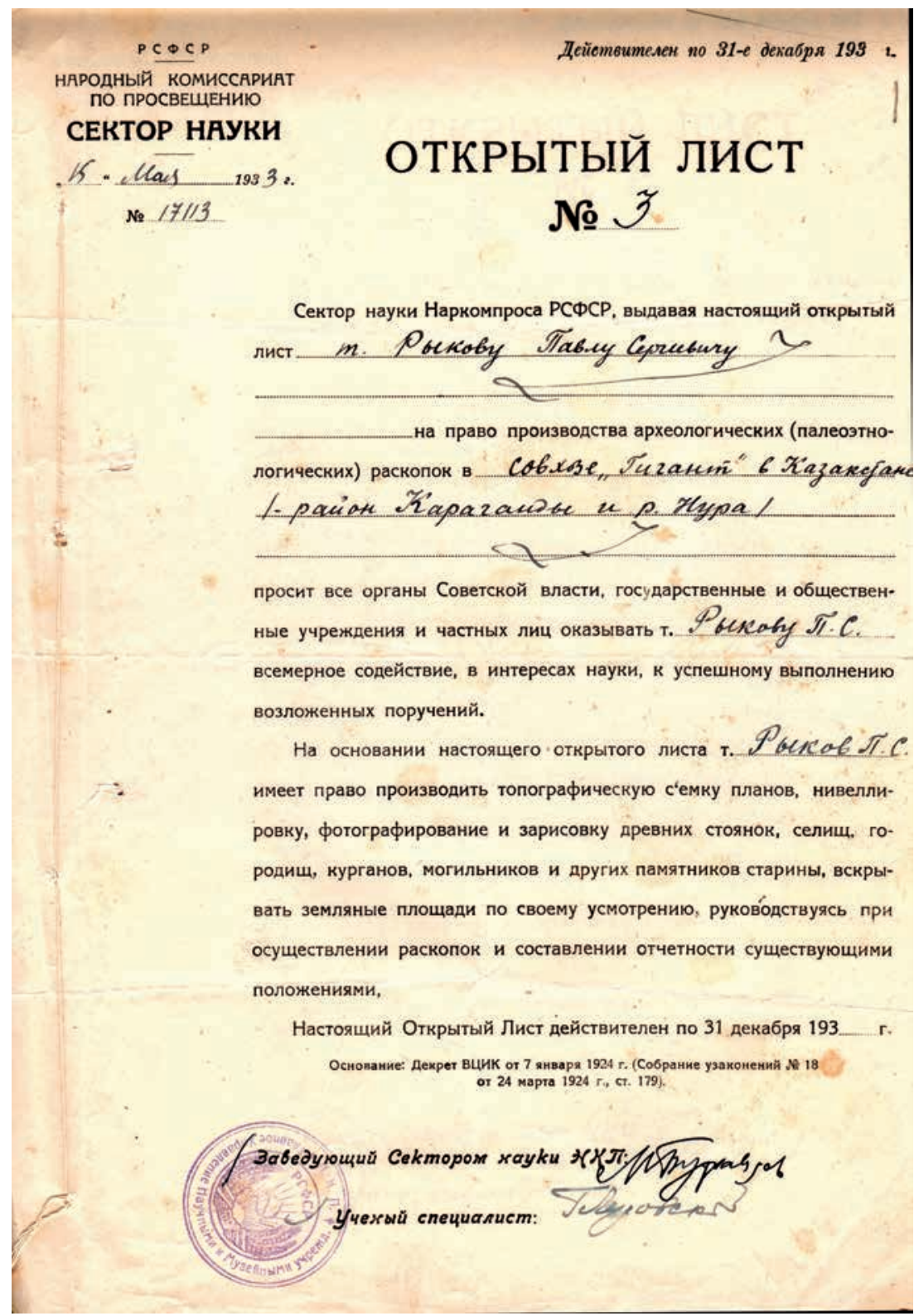

Рис. 6. Открытый лист, выданный начальнику Нуринской экспедиции ГАИМК П. С. Рыкову. Публикуется впервые (по: [Отчеты и переписка о раскопках..., л. 1])

Fig. 6. Excavation licence given to director of Nura expedition of GAIMK P. S. Rykov. First publication (after: [In NA IIMK RAN, sheet 1])

Причем последний «акт» был подписан представителями обеих сторон: заместителем начальника экспедиции ГАИМК М. П. Грязовым и начальником Карлага М. М. Чунтоновым.
Наряду с этим, подробные сведения о разведках, раскопанных объектах и руководителях работ на каждом объекте помещены в «отчете», опубликованном во втором томе 
«Археологических работ Академии на новостройках в 1932-33 гг.» [Рыков, 1935. С. 40-68].

Полевой этап работ Нуринской экспедиции

Анализируя вышеупомянутые документы, нетрудно выявить некоторые важные черты, характеризующие работу Нуринской экспедиции ГАИМК. Без сомнения, она носила рекогносцировочный характер и рассматривалась ее организаторами, прежде всего академией, как первый этап большого, длительного проекта, который мог быть осуществлен только с полного одобрения ГУЛАГ ОГПУ и при поддержке его администрации. Именно этот формат взаимоотношений был успешно реализован в 1933 г. За полтора месяца полевых работ - с 14 июня по 3 августа при материальной и технической поддержке ГУЛАГа, в том числе поставлявшего рабочую силу для раскопок, экспедиция П. С. Рыкова обследовала значительную территорию Центрального Казахстана, практически неизвестную с археологической стороны, а тогда и закрытую для свободного посещения. Членами экспедиции был исследован ряд разновременных археологических памятников, преимущественно погребений, среди которых обнаружен неизвестный ранее тип сооружений первый памятник будущей бегазыдандыбаевской культуры - курган № 11 могильника Дандыбай.

Экспедиция 1933 г. сосредоточилась на раскопках небольших объектов в разных частях обследованной территории, что, несомненно, объяснялось как незначительными силами (6-7 человек штатного состава и небольшое, неравномерно предоставляемое количество рабочих из контингента заключенных Карлага), так и чисто спасательным характером исследований - нужно было затронуть раскопками как можно больше разнообразных типов памятников в разных местах, чтобы на основе полученных данных составить верное представление о перспективах их изучения и историко-культурной ситуации в районе работ. Более масштабные раскопки планировались на следующий год.

Взаимоотношения руководства экспедиции и администрации Карлага, судя по отчетам П. С. Рыкова, складывались весьма удачно, а «внимательное и предупредительное» отношение начальника лагеря и его заместителя к членам экспедиции и ее надобностям можно объяснить как личными качествами начальника Карлага М. М. Чунтонова и его заместителя О. Г. Линина, так и их нацеленностью на взаимовыгодное сотрудничество с археологами, появившимися здесь по разрешению головного учреждения - ГУЛАГ ОГПУ. Об этом свидетельствует их заинтересованное участие, выразившееся и в своевременном издании приказа о необходимости учета и охраны памятников на территории лагеря, и в предоставлении возможности опубликовать культурно-просветительскую информацию о работах экспедиции на страницах лагерной газеты «Путевка», а также в переговорах о создании краеведческого уголка в музее лагеря в с. Долинском.

Мы ничего не знаем о взаимоотношениях участников экспедиции и рабочих-землекопов, выделяемых администрацией Карлага в помощь археологам. Ни П. С. Рыков, ни М. П. Грязнов, ни другие члены экспедиции по понятным причинам записей об этом не оставили. Немыми свидетелями участия заключенных Карлага в работе экспедиции 
Смирнов Н.Ю. Неизвестный контекст знаменитого открытия: работа М.П. Грязнова...

ГАИМК остаются немногочисленные любительские полевые фотографии [Нуринская экспедиция ГАИМК...], сделанные, скорее всего, Н. К. Арзютовым и запечатлевшие моменты расчистки насыпей курганов и разборки наземных сооружений, на которых иногда видны одинаково одетые фигурки людей с лопатами в руках, выполняющих простую землекопную работу (рис.7). К сожалению, все кадры профессиональной полевой съемки до нас не дошли - ящик с отснятыми материалами потерялся или был украден в дороге, по пути следования экспедиционного груза из Караганды в Ленинград [Переписка по организации работ..., л. 53].

Ситуация с финансированием экспедиции напоминала ту, что нередко можно наблюдать в наши дни. Работы ГАИМК, параллельно шедшие на других новостройках, также занимали время сотрудников, а их недостаточное или несвоевременное финансирование приводило к тому, что академия была вынуждена переводить деньги со счета одной экспедиции на счет другой, чтобы своевременно покрывать командировочные и полевые издержки. Так, М. И. Артамонову, уезжавшему из Казахстана в собственную экспедицию на Маныч, деньги на проезд были выделены из средств Нуринской экспедиции. Неудивительно, что П. С. Рыков и М. П. Грязнов так часто напоминали в переписке с Б. А. Латыниным, и с Комитетом по новостройкам в целом, о необходимости перевода авансов для приобретения билетов и прочих нужд экспедиции [Переписка по организации работ..., л. 66, 68, 69, 71 и др.].

13 июня, спустя неделю, ушедшую нато, чтобы добраться от Москвы до Караганды, экспедиция прибыла «к месту работ в с [ело] Долинское $и$ в тот же день приступила к полевой работе», о чем свидетельствует ее первый отчетный «акт» [Переписка по организации работ..., л. 75]. Несколько иначе первые дни работы описаны в письме № 1, отправленном в ГАИМК на четвертый день приезда в Казахстан - 16 июня. Из него следует, что экспедиция прибыла «в базовый пункт своих работ»- - . Долинское, вечером 13 июня, а после проведения «организационных мероприятий» в первой половине дня 14 июня действительно сразу приступила к разведкам. При этом за два с половиной дня члены экспедиции прошли или проехали (это не ясно из письма) пять маршрутов «общим протяжением до $100 \kappa$ [илометров]». В результате разведок был собран подъемный материал, обнаружены и картированы памятники. Некоторые из них были «намечены к раскопкам» как «находящиеся в зоне строительных работ». Вечером 16 июня экспедиция должна была перебраться на новое место для продолжения разведок [Переписка по организации работ..., л. 65].

16 июня, перед отъездом из административного центра Карлага, в адрес Комитета по новостройкам ГАИМК М. П. Грязнов отправляет еще одно письмо (№ 2) с просьбой как можно скорее перевести оставшиеся по смете деньги экспедиции на его имя. Именно из него мы и узнаем, что члены экспедиции числились в административной структуре Карлага как «вольнонаемные» [Переписка по организации работ..., л. 66].

Через 10 дней после окончания следующего этапа разведок, 26 июня, П. С. Рыков и М. П. Грязнов отправляют в академию письмо № 3, в котором описывают достижения экспедиции, отмечая, что «предварительное археологическое обследование изуча- 
емого района в основном ею закончено». За этот период были осмотрены памятники «как северного, так и южного участков» совхоза "Гигант", попадавших в зону обследования, причем 160 км маршрутов было пройдено пешком, а более 570 км преодолено на автомашинах. Для раскопок «с охраннылми цеелями» экспедиция выбрала 10 групп памятников, сосредоточенных в двух пунктах. Приступить к раскопкам руководители экспедиции планировали в ближайшие дни. Атмосфера, в которой приходилось работать экспедиции, описывалась лапидарно: «Общий ход работ

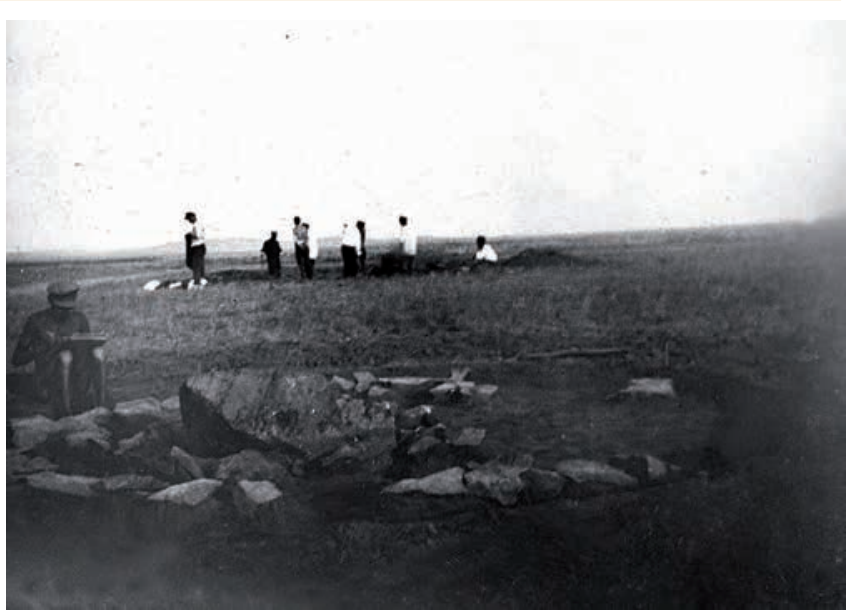

Рис. 7. Хут. Центральный у р. Чурубай-нура, курган № 5. Общий вид раскопок.

На переднем плане, возможно, Н.К. Арзютов. На заднем плане - рабочие - заключенные Карлага и кто-то из сотрудников экспедииии. Публикуется впервые [по: Нуринская экспедичия ГАИМК ..., о. 1029.23]

Fig. 7. Tsentralny Farmstead near the Churubay-Nura River, barrow no. 5. General view of the excavations. In the foreground, possibly, N. K. Arzyutov.

In the background, workers (prisoners) of Karlag (Karaganda Penitentiary Labour Camp) and an assistant of the expedition. First publication (after: In NA IIMK RAN, print 1029.23])

\section{считаем нормальным.}

Местные власти обеспечивают своим содействием работу экспедиции〉 [Переписка по организации работ..., л. 67].

28 июня П. С. Рыковым и М. П. Грязновым был составлен второй «акт» о выполненных работах, в котором отмечалось, что «при разведках собраны материаль для составления археологической карты исследуемого района, выявлены памятники подлежащче охране и намечень пункты раскопок памятников, иелости которых угрожают хозяйственные работы совхоза». Также руководство экспедиции уведомляло Комитет по новостройкам академии о том, что «23 июня с [его] г[ода] к составу экспедииии присоединился и приступил $\kappa$ работе стари[ий] научн[вый] сотрудник М. И. Артамонов» [Пере- писка по организации работ..., л. 74]. М. И. Артамонов выехал в поле позднее, задержавшись в Ленинграде для окончания своих дел в Эрмитаже.

Таким образом, с 14 по 28 июня экспедиция посредством автомобильных и пеших разведок в полном составе или малыми группами (по 2-3 человека) обследовала обширную местность в совхозе "Гигант", включающую, в административном отношении, - семь отделений Карлага. Основные разведочные маршруты экспедиции пролегли по рр. Нуре, Чурубай-Нуре, Джаксы-Сары-Су и Джаман-Сары-Су. Общая протяженность маршрутов за весь срок работы экспедиции составила более 1500 км. Автомобили и продовольствие были предоставлены руководством Карлага [Рыков, 1935, с. 40; Докладная 
Смирнов Н.Ю. Неизвестный контекст знаменитого открытия: работа М.П. Грязнова...

записка начальника..., л. 51-51 об.; Переписка по организации работ..., л. 81 об.].

5 июля 1933 г. из экспедиции было отправлено письмо № 4, в котором описывались исследования, проведенные с 27 июня по 5 июля. В этот период экспедиция закончила разведки - было «пройдено пешком $23 \kappa[$ илометра] и на машине до $230 \kappa[$ илометров]», и начала раскопки в одном из выбранных пунктов, расположенном у каменоломен. Здесь были исследованы разрушаемые при хозяйственных работах Карлага курганы преимущественно андроновской культуры. Рядом с ними, на возвышенности, члены экспедиции собрали подъемный материал - каменные орудия, однако при шурфовке следов поселения выявлено не было.

В день отправки письма экспедиция переезжала на другое место работы.

Привлекает внимание характерная приписка в конце письма, в которой П. С. Рыков и М. П. Грязнов напоминают Комитету по новостройкам о том, что обещанные академией деньги на окончание экспедиции и возвращение домой так до сих пор и не получены [Переписка по организации работ..., л. 70-70 об.].

На самом деле, академия еще 7 июля перевела М. П. Грязнову «обычной почтой» 4000 рублей, остававшихся на счетах, по смете Нуринской экспедиции. Но, ввиду значительности расстояния, эти деньги шли очень долго [Переписка по организации работ..., л. 68].

Основной период раскопок пришелся на июль месяц. Об этом нам повествуют оставшиеся три письма и ряд других документов.

Так, 16 июля из экспедиции было отправлено письмо № 5, в ко- тором кратко описывались результаты работ за 10 дней - с 5 по 15 июля. Раскопки велись вдоль р. Нуры, где изучались курганы в основном андроновского периода, но также были открыты погребения более позднего времени: сарматское и, вероятно, средневековое. При технической поддержке администрации Карлага в этот же период членами экспедиции были осуществлены дополнительные разведки - автомобильные поездки на расстояние в 150 км в «центральный район исследуемой территории». К моменту отправки письма раскопки на р. Нуре были закончены и экспедиция перебиралась на новое место [Переписка по организации работ..., л. 72].

22 июля из Долинского управления Карлага в Комитет по новостройкам ГАИМК летит телеграмма, подписанная П. С. Рыковым, М. П. Грязновым и М. И. Артамоновым, уже с категорическим требованием выслать обещанные деньги на счет экспедиции. Наряду со все еще неполученными деньгами на окончание Нуринской экспедиции, речь шла о том, что академия должна была перевести еще и деньги на экспедицию М. П. Грязнова на Калбинские рудники, а также деньги для М. И. Артамонова, предназначенные ему на дорогу до собственной экспедиции на Маныче. После этого, третьего по счету напоминания, ГАИМК наконец-то высылает требуемые деньги, но не полностью. К отправленным ранее по почте средствам Нуринской экспедиции прибавляются 2000 рублей на экспедицию М. П. Грязнова, высланные 23 июля телеграфом. А вот 250 рублей на проезд М. И. Артамонова из Караганды до Манычской экспедиции Комитет по новостройкам распоряжается вы- 
дать из «нуринских» [Переписка по организации работ..., л. $68,69,71]$.

29 июля следует очередное письмо (№ 6) из экспедиции, которая уже 13 дней «производит охранительные раскопки» в восточной части Карлага, в двух местах по р. ЧурубайНуре. Основные изучаемые здесь памятники относятся к андроновскому периоду, но открыты также и более поздние, интерпретируемые как «сарматские» - «с дольменами в иентральных частях курганов». Несмотря на окончание основного периода разведок, члены экспедиции проходят пешими и проезжают автомобильными разведочными маршрутами по району, прилегающему к западу к p. Чурубай-Нуре, в общей сложности 64 км [Переписка по организации работ..., л. 79].

3 августа 1933 г. П. С. Рыков и М. П. Грязнов отправляют из экспедиции последнее письмо (№ 7), в котором пишут о том, что работы экспедиции на р. Чурубай-Нуре завершены. Среди исследованных памятников преобладали курганы андроновской эпохи, но были и более поздние, в том числе «1 большая могила с квадратной каменной оградой - раннескифского времени», в которой, вопреки неожиданному описанию, достаточно уверенно опознается курган № 11 могильника Дандыбай. Отмечая повальное разграбление исследованных памятников еще в древности, исследователи все же полагали, что «раскопки дали достаточный материал для характеристики освещзаемых ими эпох» [Переписка по организации работ..., л. 76].

Тем же 3 августа датирован третий отчетный «акт», составленный П. С. Рыковым и М. П. Грязновым, из которого мы узнаем, что все полевые 96 работы закончены 1 августа. Еще два дня -2 и 3 августа ушли на окончание работ по сворачиванию экспедиции, а также на упаковку и отправку коллекций в Ленинград [Переписка по организации работ..., л. 73].

Всего Нуринской экспедицией ГАИМК с 29 июня по 1 августа «в $2 x$ пунктах по р[еке] Нуре и в 4 пунктах по $р$ [еке] Чурубай-Нуре» было изучено 32 «могильных сооружения», содержавших 43 захоронения, и «обследованы детально» два поселения [Рыков, 1935, с. 41; Переписка по организации работ..., л. 73, 81 об.].

Если отталкиваться от опубликованного списка руководителей раскопов, а также своеобразного подсчета количества участников разведок (всегда на одного человека меньше, чем было членов экспедиции), то может создаться впечатление, что начальник экспедиции, профессор П. С. Рыков, в самих полевых работах непосредственного участия не принимал, возможно, занимаясь общей координацией и сношениями с начальством Карлага. К схожему выводу пришел и С. С. Тихонов, опиравшийся на опубликованные данные о руководителях раскопов [Тихонов, 2009, с. 189, табл. 1]. Однако есть свидетельство того, что П. С. Рыков непосредственно участвовал в разведках. Имеется его отчет, озаглавленный «Маршрут П. С. Рыкова (обследования Нуринской экспедициии)» из которого понятно, что он, как минимум, занимался полевыми исследованиями в формате разведок [Отчеты и переписка о раскопках..., л. 18-20]. Косвенным свидетельством его непосредственного участия в раскопках служит опись фотографий, сохранившаяся в полевом дневнике И. В. Синицына, где в описании кадров П. С. Рыков нередко фигурирует на раскопе [И.В. Сини- 
Смирнов Н.Ю. Неизвестный контекст знаменитого открытия: работа М.П. Грязнова...

цын. Черновые дневниковые заметки..., л. 22-24 об.].

М. П. Грязнов, по подсчетам С. С. Тихонова, во время работы экспедиции руководил раскопками восьми объектов [Тихонов, 2009, табл. 1]. Кроме него начальниками раскопов были также имевшие открытые листы Н. К. Арзютов, М. И. Артамонов и И. В. Синицын. М. Н. Комарова и А. Н. Рогачёв в качестве руководителей полевых работ не упоминаются. Возможно, они были помощниками руководителей раскопов или занимались полевой фиксацией [Рыков, 1935; Переписка по организации работ..., л. 81 об.]. По отношению к А. Н. Рогачёву это можно утверждать точно, так как П. С. Рыков в письме М. П. Грязнову, отправленном из Саратова после окончания экспедиции, упоминает о «чертежах А. Н. Рогачёва курганов Дындыбая» [Рыков Павел Сергеевич..., л. 3 об.].

Понятно, что раскопки, в указанном выше объеме могли быть осуществлены экспедицией лишь при наличии определенного рода «помощников»-заключенных, направленных на полевые работы администрацией Карлага. Если С. С. Тихонов только предполагал это, по сути, проецируя общеизвестную практику применения труда заключенных на «великих стройках социализма» на конкретную ситуацию с проведением археологических работ на территории Карлага [Тихонов, 2009, с. 189], то я могу это уже утверждать, опираясь на документальные свидетельства. Жаль, что имена этих «добровольных» помощников история нам не сохранила.

В отчете в Комитет по новостройкам П. С. Рыков обобщенно пишет о том, что экспедиции была предоставлена «рабочая сила разного качества и в разном количестве - от 2 до
20 человек» и сетует на то, что более крупные объекты невозможно было исследовать «в виду затруднений с рабочей силой, занятой на срочных работах» [Переписка по организации работ..., л. 81 об.]. Абсолютно ясно, что непрофильная занятость заключенных на археологических раскопках входила в противоречие с первоочередными задачами социалистического строительства в гигантском хозяйстве Карлага, и начальство лагеря отправляло на помощь археологам, скорее всего, не самых работоспособных из них и, вероятно, вообще в этом случае подходило к решению вопроса по остаточному принципу.

Впрочем, по воспоминаниям М. П. Грязнова, они просили лагерное начальство назначать на работы заключенных из «интеллигентов», причем последние были очень рады принять участие в научном исследовании [Устное сообщение Н. А. Боковенко].

В отчете начальнику Карлага М. М. Чунтонову П. С. Рыков характеризует помощь администрации лагеря более комплиментарно, но приводит и более точные сведения о работе заключенных: «Всего было употреблено на работу, считая лишь часы применения рабочей силы - от штрафрот - до 214 час[ов], причем количество рабочих колебалось от 2 до 20 человек» [Докладная записка начальника..., л. 51 об.].

Кроме решения организационно-технических вопросов помощь в размещении, снабжение питанием и автотранспортом, предоставление рабочей силы, была и другая сфера взаимодействия администрации Карлага и экспедиции ГАИМК, связанная с «культурнопросветительской деятельностью» 
и охраной памятников археологии. По общему договору с ГУЛАГом археологи были обязаны подготовить и распространить инструкцию по охране памятников на новостройках, прочесть курс лекций и организовать музей. Сразу скажу, что из всего перечисленного, видимо, не удалось сделать ничего или почти ничего: инструкция так и не была доставлена в Карлаг до окончания работы экспедиции, о лекциях никаких четких сведений в достаточно подробных отчетах П. С. Рыкова найти нельзя (есть лишь туманное упоминание о каком-то его докладе, после которого был издан приказ об охране памятников), а музей, как оказалось, уже имелся при учебном комбинате в с. Долинском и его нужно было, впоследствии, лишь дополнить наглядными материалами. С этим сюжетом также не все ясно. Сведений об отправке в музей при учебном комбинате в с. Долинском каких-либо наглядных пособий, иллюстрирующих древнюю историю Центрального Казахстана, в документах не содержится. По моим предположениям, подготовкой таких пособий должен был заниматься М. П. Грязнов, но по причинам, о которых пойдет речь ниже, он надолго оказался оторван от решения задач и воплощения планов Нуринской экспедиции, в том числе связанных с обработкой полевого материала.

Единственные успешные шаги в направлении просвещения местного «населения» и охраны памятников археологии, предпринятые П. С. Рыковым и М. П. Грязновым при поддержке администрации Карлага, состояли в следующем: были изданы три статьи в местной газете «Путёвка», из которых в имеющихся документах присутствует только одна (рис. 8), и достигнута догово98 ренность об издании специального приказа по лагерю, обеспечивавшего «охрану древних сооружений» [Переписка по организации работ..., л. 82; Докладная записка начальника..., л. 51]. Приказ по Карагандинскому Исправительно-Трудовому лагерю ОГПУ под номером 306 действительно был издан 17 июля 1933 г., в разгар работы экспедиции ГАИМК (рис. 9), однако насколько он повлиял на сохранность памятников археологии на территории Карлага, осталось неизвестно.

Раскопки эпонимного памятника будущей бегазы-дандыбаевской культуры - кургана № 11 на могильнике Дандыбай, как уже говорилось выше, имели место на финальном этапе полевых работ, в период с 29 июля по 1 августа 1933 г. Любопытно, что при первом упоминании кургана он был назван «ранне-скифским» [Переписка по организации работ..., л. 76].

Видимо, такая интерпретация была для П. С. Рыкова и М. П. Грязнова сугубо рабочей и предварительной, так как в дальнейшем во всех текстах этот курган фигурировал как памятник карасукской культуры. Впрочем, к занимательной истории его интерпретации я вернусь позднее.

Исследованием объекта руководил М. П. Грязнов, чертежи делал, вероятно, он сам, хотя есть упоминание о том, что какие-то чертежи курганов Дандыбая делал А. Н. Рогачёв (см. выше). Некоторое представление о процессе раскопок дают любительские снимки Н. К. Арзютова (рис. 10-13).

Данные, полученные в процессе изучения кургана № 11, были введены в научный оборот дважды: в первый раз - в обобщающем отчете об экспедиции, написанном П. С. Рыковым на основании отчетов руководителей раскопов [Рыков, 1935], а во 
Смирнов Н.Ю. Неизвестный контекст знаменитого открытия: работа М.П. Грязнова...

второй - в большой аналитической статье автора раскопок кургана М. П. Грязнова [Грязнов, 1952]. Все это позволяет мне далее, не останавливаясь на разборе хорошо известных материалов памятника, обратиться к изложению истории его осмысления М. П. Грязновым в период между окончанием раскопок в 1933 г. и выходом статьи 1952 г.

После сворачивания экспедиции и отправки коллекций состоялся отъезд основной части ее участников из Казахстана, в том числе уехал и П. С. Рыков. Заключительный «акт» об исполнении всех пунктов договора между академией и ГУЛАГ ОГПУ и завершении программы работ «Казакстанской экспедиции ГАИМК» со стороны экспедиции 8 августа 1933 г. подписал заместитель начальника - М. П. Грязнов. Он остался в Казахстане, так как должен был после окончания Нуринской экспедиции отправиться в новую, уже свою экспедицию по изучению древних выработок олова и золота в Калбо-Нарымском крае и ждал высылки денег, открытого листа и удостоверения [Грязнов, 1935; Переписка по организации работ..., л. 69, 71, 77].

Со стороны Карагандинского ИТЛ «акт» был подписан начальником лагеря - М. М. Чунтоновым. Подписи сторон удостоверяли то, что «работы по археологическому обследованию, выявлению и учету памятников u проведение археологических раскопок на территории совхоза "Гигант" вылолнены полностью» [Переписка по организации работ..., л. 78].
Камеральный этап работ Нуринской экспедиции

По дороге из Караганды в Ленинград, как я уже писал, пропали некоторые полевые материалы, отправленные из экспедиции по железной дороге [Переписка по организации

\section{НА КУЛЬТУРНО-ВОСПИТАТЕЛЬНОМ}

\section{Научншя ирхеологическия экспепиция.}

Партил и Советская нтасть постави- метов материальной культуры, под

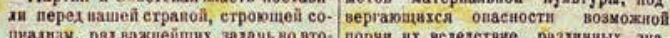

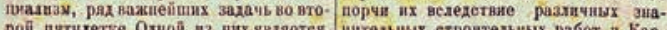

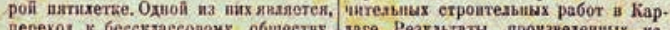

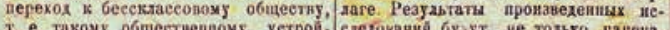
т. е. такому общестнепиом уетрой- слехоканай бу ут не только папеча-

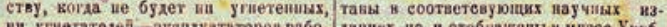

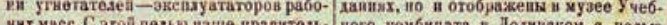

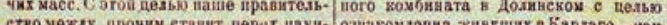

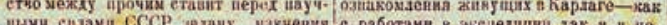

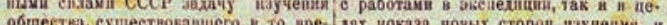

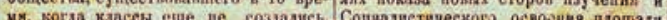

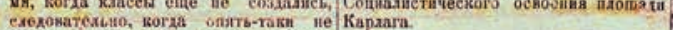

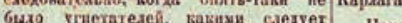

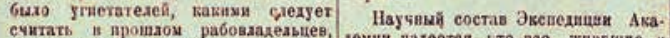

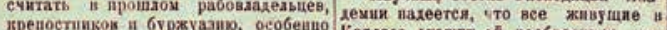

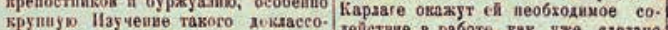

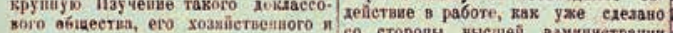

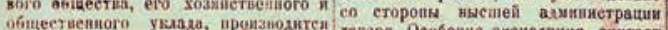

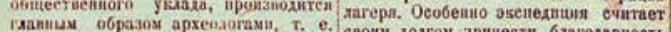

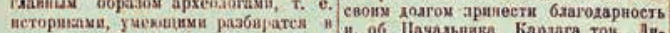

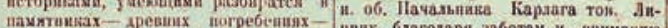

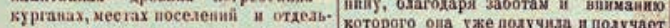

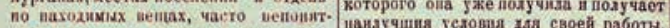

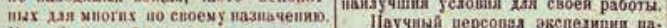

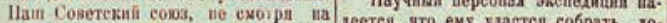

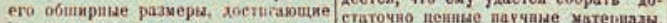

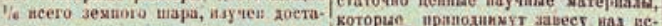

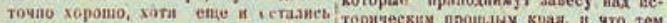

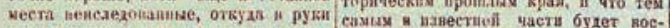

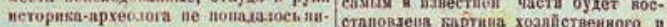
каких спедений о дрениих паматниках

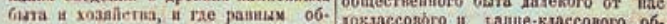
разом не пронтодались археологиче-- іместа.

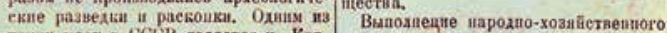

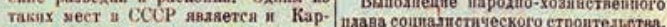

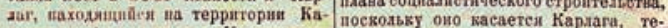

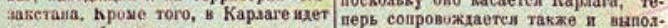

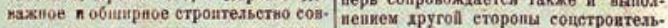

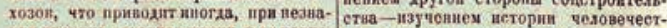

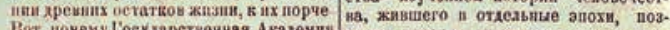

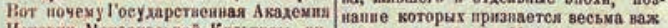

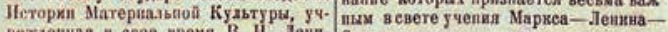
pexicmas в cвoе иремя B. H., Jeil- Crasma.

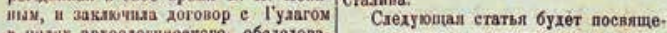
n пезих археологичеекого обеледова- ша указанилм инетруктивного характе-

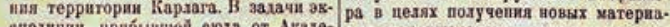

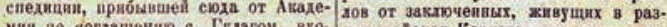

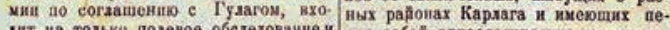
дит пе тодько подевое обслехование и

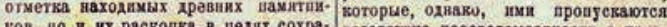
ков, ио и их расвопка в целих сохра- велехетвие веосведомдеваости в пнте.

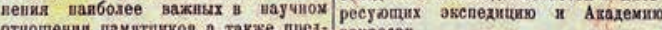

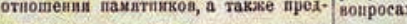

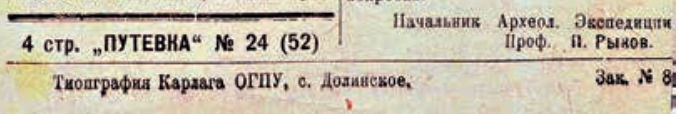

Рис. 8. Статья П. С. Рыкова в газете «Путёвка», издаваемой в Карагандинском ИТЛ. Публикуется впервые (по: [Докладная записка начальника..., л. 50])

Fig. 8. Article by P. S. Rykov in the newspaper "Putyovka" issued at the Karaganda Penitentiary Labour Camp. First publication (after: [In SPbF ARAN, sheet 50]) 
работ..., л. 53]. В том числе был утрачен основной массив полевых фотографий. Остальные материалы - археологические находки, полученные в ходе работы экспедиции, - благополучно добрались до Ленинграда и поступили на камеральную обработку в ГАИМК. Их нужно было разобрать, зашифровать, отреставрировать, в общем, провести обычные камеральные работы, которые сейчас, зачастую, проводятся еще в полевых условиях, особенно в крупных новостроечных экспедициях. По всей видимости, руководство камеральной работой в Ленинграде было поручено М. П. Грязнову, в помощь которому П. С. Рыков обещал откомандировать из Саратова И. В. Синицына и Н. К. Арзютова [Рыков Павел Сергеевич..., л. 2-3 об.].

Из сметы на камеральную обработку находок Нуринской экспедиции известно, что общая стоимость работ составила 2050 р., а срок их выполнения был ограничен двумя месяцами. В перечень работ входили: разборка полевых коллекций, составление описи, определение костей животных и человека, проведение естественнонаучных анализов, изготовление чертежей и рисунков, фотоработы, оформление двух экземпляров отчета с текстовой и альбомной частями [Переписка по организации работ..., л. 84, 86, 87].

Отдельную задачу представляла собой реставрация находок и антропологических материалов. Несмотря на то, что в ГАИМК существовала своя реставрационная лаборатория, решено было передать керамику и кости для реставрации в Русский музей. Что явилось истиной причиной такого решения сказать сейчас трудно, но были два момента, которые могли оказаться ключевыми в вопросе о том, кто именно будет реставрировать находки. Первый момент заключался в том, что заместитель начальника Нуринской экспедиции М. П. Грязнов по месту основной работы числился именно в Этнографическом отделе Русского музея и мог, таким образом, непосредственно контролировать весь процесс реставрации находок. Кроме того, в свое время условием для его откомандирования в состав Нуринской экспедиции было то, что ГАИМК гарантировал Русскому музею преимущественное право на получение коллекций экспедиции [Переписка по организации работ..., л. 60]. Второй, не менее, а, возможно, и более 
Смирнов Н.Ю. Неизвестный контекст знаменитого открытия: работа М.П. Грязнова...

важный для академии сюжет состоял в том, что Русский музей брал на себя финансирование расходов на реставрацию археологических предметов с тем, чтобы включить их в последствие в свои фонды, а, возможно, и в экспозицию [Переписка по организации работ..., л. 83, 85]. Переговоры с Русским музеем о реставрации находок шли на протяжении сентября октября и закончились успешно. При этом директор Русского музея с удовлетворением отмечал «возобновление передач археологических собраний Гос[ударственой] Академией Материальной Культуры Русскому Музею» и выражал надежду на то, что «связь в этом отношении между ГАИМК и Русским Музеем в дальнейшем еще более окрепнет» [Переписка по организации работ..., л. 83].

Если финансировать реставрацию находок согласился Русский музей, то остальные расходы, связанные с проведением камеральной обработки

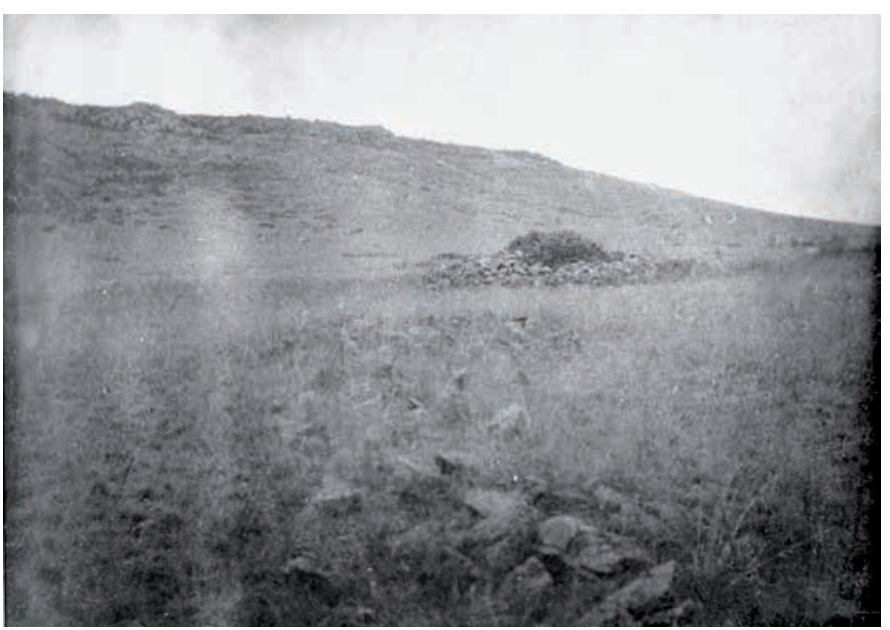

Рис. 10. Вид на сопки в районе аула Дандыбай. Внизу «казакские могилы, покрытые камнями». Публикуется впервые (по: [Нуринская экспедиция ГАИМК ..., о. 1029.30])

Fig. 10. View at the hills in the vicinity of aul Dandybay. Below 'Kazak graves covered with stones'. First publication (after: [In NA IIMK RAN, print 1029.30]) материалов экспедиции, согласно смете, относились на счет ГУЛАГа [Переписка по организации работ..., л. 84].

10 октября 1933 г. П. С. Рыков из Саратова отправляет М. П. Грязнову последнее письмо, касающееся дел Нуринской экспедиции. Из него следует, что работа над чертежами и рисунками, а также печатание фотографий осуществлялись в Саратове. Фотографии, видимо, те самые, любительские, сделанные Н. К. Арзютовым, печатались П. С. Рыковым частично за счет средств по смете на камеральную обработку, а частью за счет «местных средств» (самые неудачные, а также «бытовые»). Обсуждался и вопрос отчетных материалов: отправлять ли их по почте или подождать до отъезда в Ленинград Н. К. Арзютова и И. В. Синицына и отправить с ними полевые дневники, фотографии и изготовленные чертежи с рисунками? Сам П. С. Рыков не собирался появляться в ГАИМК ранее декабря, так как предполагал, что камеральная обработка не закончится раньше этого времени, к тому же служебные обстоятельства в Саратове препятствовали его приезду в ноябре - он должен был читать лекции студентам. Вместе с письмом П. С. Рыков отправил «подписанную ведомость» (видимо, расходную или зарплатную), «карту» (вероятно, топографический план места работ, выданный в ОГПУ или в Карлаге) и «чертежи курганов Дындыбая», 
сделанные А. Н. Рогачёвым [Рыков Павел Сергеевич..., л. 2-2 об.].

В течение октября и ноября в Саратове и Ленинграде шли камеральные работы и готовился отчет Нуринской экспедиции. В соответствии с программой работ экспедиции, согласованной с ГУЛАГом еще в мае 1933 г., камеральная часть должна была быть завершена к 25 ноября 1933 г., а отчет закончен спустя месяц - к 25 декабря. В конце 1933 г. ГАИМК должна была

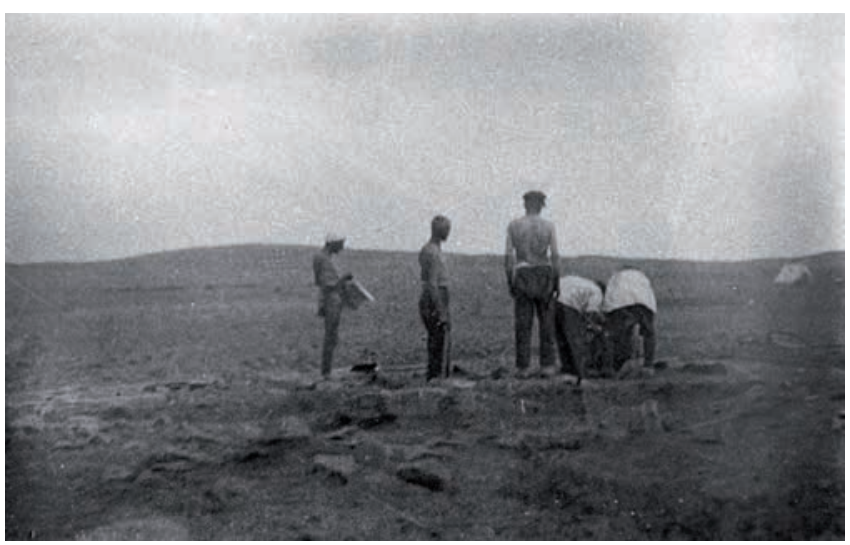

Рис. 11. Могильник у аула Дандыбай. Курган № 11. Начало раскопок. Публикуется впервые (по: [Нуринская экспедииия ГАИМК ..., о. 1029.44])

Fig. 11. Burial ground near aul Dandybay. Barrow no. 11. Beginning of excavations. First publication (after: [In NA IIMK RAN, print 1029.44]) организовать отчетную

выставку «всего добытого материала» [Переписка по организации работ..., л. 93].

Арест М. П. Грязнова и его последствия. Первая попытка осмысления материалов кургана № 11

Мерный ход камеральных работ и подготовки общего отчета экспедиции, которым занимался М. П. Грязнов, внезапно был нарушен той же самой могущественной организацией, подразделение которой было заказчиком работ в совхозе "Гигант". 29 ноября 1933 г. М. П. Грязнов был арестован по обвинению в принадлежности к «фашистской контрреволюционной организации украинских националистов», заключен в тюрьму, где содержался во время следствия на протяжении четырех месяцев (с декабря 1933 г. по март 1934 г.) и допрашивался сотрудниками Секретнополитического отдела Управления ОГПУ по Ленинградской области [Ашнин, Алпатов, 1994, с. 34, 40; Заявление..., 2002, с. 86-90]. Той же осенью 1933 г. был арестован целый ряд музейных и научных работников Ленинграда и Москвы в рамках сфабрикованного ОГПУ дела «Российской национальной партии». В Этнографическом отделе Русского музея, где работал М. П. Грязнов, были арестованы его ближайшие коллеги Г. А. Бонч-Осмоловский, Д. А. Золотарёв, А. А. Миллер, С. А. Теплоухов, Ф. А. Фиельструп [Ашнин, Алпатов, 1994, с. 34-40]. Судьба четырех из пяти коллег М. П. Грязнова сложилась трагически: С. А. Теплоухов и Ф. А. Фиельструп погибли или покончили с собой в тюрьме во время следствия, Д. А. Золотарёв и А. А. Миллер умерли в лагерях и ссылке, причем А. А. Миллер - в Казахстане [Ашнин, Алпатов, 1994, с. 202-206].

25 марта 1933 г. М. П. Грязнов был признан виновным «в участии в Фашистской контрреволюционной организации украинских и русских националистов» и приговорен к трехлетнему заключению в ИТЛ, замененному на высылку на три года «по эта- 
Смирнов Н.Ю. Неизвестный контекст знаменитого открытия: работа М.П. Грязнова...

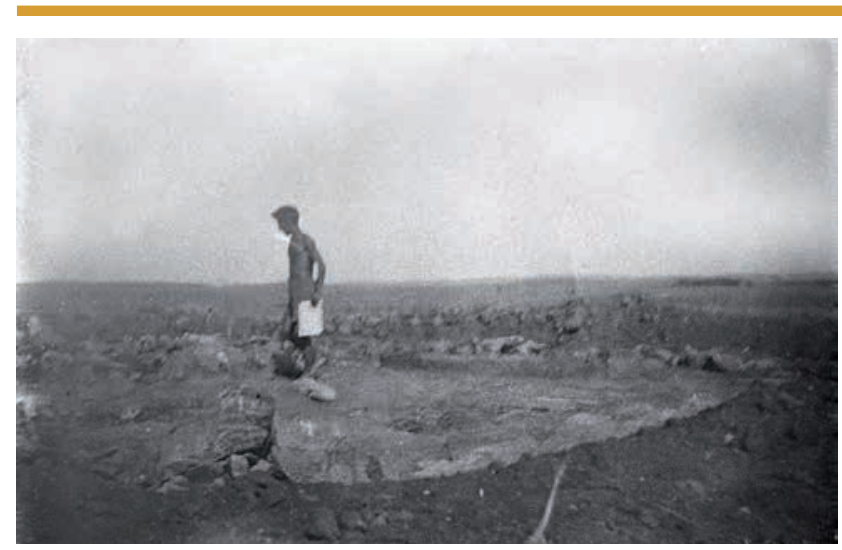

о кургане № 11 могильника Дандыбай, оставшуюся неопубликованной.

В личном фонде М. П. Грязнова в НА ИИМК РАН сохранились колоритные папки его собственного изготовления, содержащие материалы Нуринской экспедиции, причем четыре из них явно относятся к пе-

Рис. 12. Могильник у аула Дандыьбай. Курган № 11. Рабочий момент. М.П. Грязнов(?) на раскопе. Публикуется впервые (по: [Нуринская экспедичия ГАИМК ..., о. 1029.46])

Fig. 12. Burial ground near aul Dandybay. Barrow no. 11. Working moment. M. P. Gryaznov (?) at the excavation. First publication (after: [In NA IIMK RAN, print 1029.46]) риоду, предшествовавшему аресту в ноябре 1933 г. [Дандыбай 11 - памятник карасукской культуры..., л. 50-113]. Пятая папка, судя по названию, пометкам и стилю - уже послевоенная (рис. 14).

Bce папки имеют пу в Горьковский край». Высылку с весны 1934 г. до 25 декабря 1936 г. он отбывал в г. Кирове (тогда - г. Вятка) [Ашнин, Алпатов, 1994, с. 203; Заявление..., 2002, с. 86].

Так, в самый ответственный период осмысления итогов Нуринской экспедиции 1933 г. М. П. Грязнов был насильственно оторван от обработки коллекций, подготовки общего отчета и организации выставки. Видимо, последнее, что М. П. Грязнов успел передать в Комитет по новостройкам - это рукописные записи, дублированные в машинописи, с определениями антропологического материала из раскопок Нуринской экспедиции. Они поступили в Комитет 29 ноября 1933 г., в день его ареста [Отчеты и переписка о раскопках..., л. 37-52].

Однако к моменту ареста он успел не только разобрать полевую документацию - планы, чертежи, зарисовки и черновики записей, но и написать очень любопытную статью лаконичные названия, хорошо отражающие их содержание: «Дындыбай 11 памятник карасукского этапа в Казахстане», «Гигант», «1933. Чертежи», «Отработанные чертежи» и «1933. Карты» [Дандыбай 11 - памятник карасукской культуры..., л. 1-49, 50-70; 71-92; 93-99; 100-113].

Самый большой интерес среди содержащихся в них материалов вызывает черновая рукопись неопубликованной статьи, написанной, по всей видимости, осенью 1933 г. по свежим впечатлениям от раскопок кургана № 11 на могильнике Дандыбай. Все ссылки в тексте этой рукописи даются на работы, опубликованные не позднее 1930 г., а начинается она фразой: «Из исследованных минувшим летом Нуринской экспедицией памятников...» [Дандыбай 11 - памятник карасукской культуры..., л. 50-56].

Пометка «10 300 знаков», поставленная автором на рукописи, означает только одно - этот текст готовился к печати, возможно, в одном 
из изданий ГАИМК. Заметка имеет неожиданное название - «Памятник ранне-скифской эпохи в Казакстане» - оно отсылает нас к первому упоминанию об исследованиях кургана № 11 на могильнике Дандыбай в цитировавшемся выше письме № 7 от 3 (или 4) августа 1933 г., в котором также фигурировала «большая могила с квадратной оградой раннескифского времени» [Переписка по организации работ..., л. 76].

Перед нами первая попытка М. П. Грязнова проанализировать материалы погребения № 11

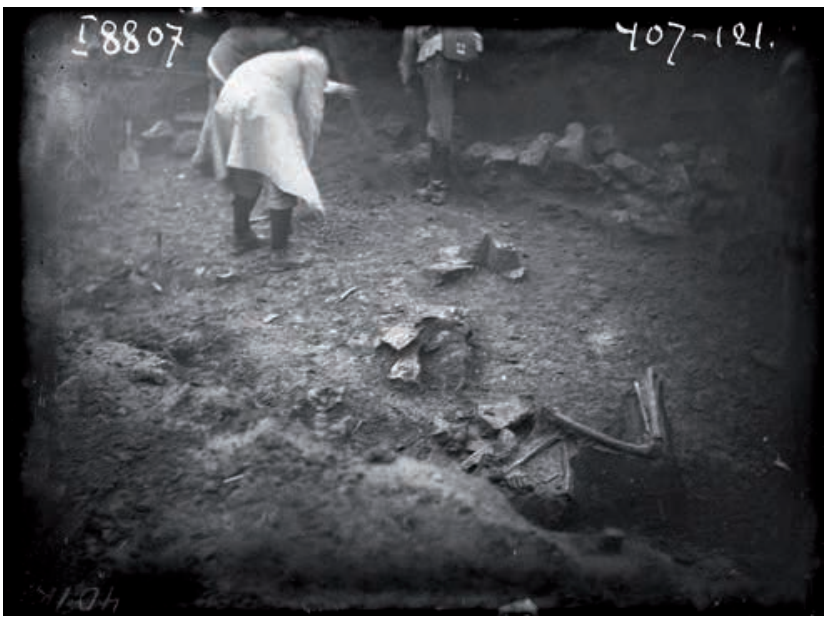

Рис. 13. Могильник у аула Дандыбай.

Курган № 11. Расчистка погребальной камеры. Публикуется впервые

(по: [Нуринская экспедиция ГАИМК..., о. 1029.47])

Fig. 13. Burial ground near aul Dandybay. Barrow no. 11. Clearing of the burial chamber. First publication (after: [In NA IIMK RAN, print 1029.47])

\section{могильника Дандыбай.}

Показательно, что в тот момент он явно затруднялся с определением хронологической и культурной принадлежности раскопанного им памятника, склоняясь в пользу скифского или предскифского возраста (в схожем ключе будут интерпретировать в первой публикации мавзолеи Бегазы и А. Х. Маргулан с Л. Р. Кызласовым [Кызласов, Маргулан, 1950]), но указывая при этом на некоторые параллели в андроновской, карасукской и скифской (причерноморской) традициях. Впрочем, отмечал он и отличительные особенности материалов памятника, не присущие трем перечисленным культурным традициям, а указанное сходство объяснял в ключе «общности социальноэкономического строя».

Важно и то, что эта невышедшая статья 1933 г. дает еще один ключик к разгадке сложения «полицентрической» или, что более верно, ацентри- ческой теории происхождения скифской культуры, кратко сформулированной М. П. Грязновым в конце жизни, при издании материалов кургана Аржан. Уже здесь, в тексте 1933 г., он достаточно четко высказывает мысль о том, что «ни для причерноморских скифов, ни для их предков нет места в Центральном Казахстане», предполагая, что «дальнейшие археологические исследования покажут, что и в других областях степей Азии не окажется родины причерноморских скифов» [Дандыбай 11 - памятник карасукской культуры..., л. 56].

Арест М. П. Грязнова помешал закончить в срок обработку материалов и написание отчета о результатах исследований Нуринской экспедиции, так как до конца 1933 г. экземпляры отчета так и не были отправлены заказчику работ - в ГУЛАГ ОГПУ, а запланированная на конец декабря выставка не состоялась. 
Смирнов Н.Ю. Неизвестный контекст знаменитого открытия: работа М.П. Грязнова...

Остается неясным - был ли командирован кто-то из Саратова в Ленинград для обработки коллекций, как это планировалось изначально. В настоящий момент я склонен полагать, что ни Н. К. Арзютов, ни И. В. Синицын не приезжали. В пользу этого свидетельствуют рукописные и печатные сопроводительные письма к отправленным из Саратова 15 декабря 1933 г. И. В. Синицыным и 20 декабря Н. К. Арзютовым по почте документам: открытым листам и полевым дневникам работ Нуринской экспедиции [Отчеты и переписка о раскопках..., л. 2, 23].

Пленум ГАИМК 1934 г. и публикация отчета о результатах работ Нуринской экспедициии

Отчетный пленум, на котором должны были быть представлены результаты работ новостроечных экспедиций ГАИМК, сначала был запланирован на середину января 1934 г., но затем перенесен на месяц позднее [Отчеты и переписка о раскопках..., л. 15,16$]$. Он шел два дня -18 и 19 февраля 1934 г. Участие в работе пленума, кроме сотрудников ГАИМК и МО ГАИМК, приняли представители других научных и музейных заведений Ленинграда, Москвы и ряда других городов. Особое значение пленума состояло в том, что он был не просто отчетным для академии, а являлся своего рода пропагандистской площадкой, так как на него были приглашены представители всех ведомств, с которыми ГАИМК работала в рамках новостроечных проектов. В перечне несомненных целей пленума были не только демонстрация успешности совместной работы с крупными государственными организациями и подтверждение необходимости продолжения спасательных работ на новостройках, но и предварительное согласование финансирования таких работ в наступившем 1934 г. К открытию пленума в ГАИМК была организована «отчетная выставка» [Стенограмма пленума..., л. 1-4]. Среди приглашенных на пленум представителей организаций-заказчиков работ есть и фамилия М. С. Госкина из 4 отделения ГУЛАГ ОГПУ, с которым в начале 1933 г. вел переговоры П. С. Рыков. Похоже, что приглашение к участию в пленуме было выслано в Карлаг и О. Г. Линину, сменившему М. М. Чунтонова на посту начальника лагеря [Стенограмма пленума..., л. 2 об, 3 об., 37].

В архиве ИИМК РАН хранятся два варианта сводного отчета о работе Нуринской экспедиции: рукописный и машинописный. Рукописный отчет написан самим П. С. Рыковым [Материалы Нуринской экспедиции..., л. 48-82] и, вероятно, является рабочим вариантом его доклада на февральском пленуме 1934 г. Перед нами сугубо деловой рассказ о ходе работ, в котором достаточно много места уделено описанию картины разрушения памятников на территории «совхоза "Гигант"» в результате сельскохозяйственных, строительных и дорожных работ. Естественно, в этом тексте, предназначенном для публичного произнесения, ни словом не упоминаются ни заказчик работ - ГУЛАГ, ни ведомство, которому управление подчиняется ОГПУ. Там, где речь заходит о взаимодействии с начальством Карлага, последнее именуется нейтрально - «администрация совхоза» [Материалы Нуринской экспедиции..., л. 48-82]. 
Арестованный М. П. Грязнов упоминается на страницах отчета в качестве заместителя начальника экспедиции [Материалы Нуринской экспедиции..., л. 50]. Его имя не замалчивается, хотя он сам находится в тюрьме уже два с половиной месяца.

Второй вариант сводного отчета Нуринской экспедиции, о котором я уже упоминал выше, - машинопись c многочисленными рукописными правками и вставками, сделанными как рукой самого П. С. Рыкова, так и редакторами Известий ГАИМК [Материалы Нуринской экспедиции..., л. 1-47]. Собственно это и есть тот вариант отчета, который был опубликован в 110 выпуске ИГАИМК в 1935 г.

Эта машинописная копия важный свидетель изменений, происходивших в ГАИМК в 1933-1935 гг. В качестве авторов текста изначально были указаны три человека: заместитель председателя ГАИМК А. Г. Пригожин, ученый секретарь комитета Б. А. Латынин и с.н.с. Нуринской экспедиции М. И. Артамонов. Затем их должности и фамилии были вычеркнуты и была вписана фамилия П. С. Рыкова, впоследствии также зачеркнутая [Материалы Нуринской экспедиции..., л. 47]. На титульном листе машинописи в ясной хронологической последовательности были оставлены три редакторские пометки. Самая ранняя из них сделана рукой Б. А. Латынина 10 мая 1934 г. Следующая по времени подпись была оставлена редактором тома И. И. Мещаниновым 18 мая 1934 г. Годом позднее, 13 февраля 1935 г., здесь появляется пространная запись Г. В. Подгаецкого: «Экземпляр, подготовленный для печати, с редакционными поправкамu» [Материалы Нуринской экспедиции..., л. 1]. Таким образом, выход статьи в свет затянулся более чем на год. За это время М. П. Грязнов был осужден и выслан в Вятку, а ситуация в академии и стране в целом стала сильно меняться в свете политических репрессий, развернувшихся после убийства С. М. Кирова в декабре 1934 г.

Наступал тяжелый и беспросветный период второй половины 1930 - первой половины 1940-х гг. Двое соратников М. П. Грязнова по экспедиции - саратовцы П. С. Рыков и Н. К. Арзютов были заключены в лагерь и погибли, ленинградец Б. А. Латынин, ученый секретарь Комитета по новостройкам, был выслан из города, а затем арестован и заключен в лагерь, где фатально подорвал свое здоровье. К занятиям наукой он смог вернуться только после 1953 г. Перестала существовать Государственная академия истории материальной культуры. Каток репрессий немного притормозил лишь с началом Великой Отечественной войны...

Конеи истории. Итоговая статья о Дандыбае 1952 г.

Завершая этот экскурс в научную биографию М. П. Грязнова начала 1930-х гг., необходимо сказать и несколько слов о предыстории его статьи 1952 г., вышедшей, почти через два десятилетия после раскопок. Столь длительная пауза, конечно, была обусловлена описанными выше событиями и их последствиями, несомненно, сказавшимися и на работоспособности ученого, и на доступности археологических материалов для дополнительного изучения. Однако есть свидетельства того, что и в этот непростой период своей жизни М. П. Грязнов не оставлял идею публикации материалов кургана № 11 могильника Дандыбай в собственной интерпретации. 
Смирнов Н.Ю. Неизвестный контекст знаменитого открытия: работа М.П. Грязнова...
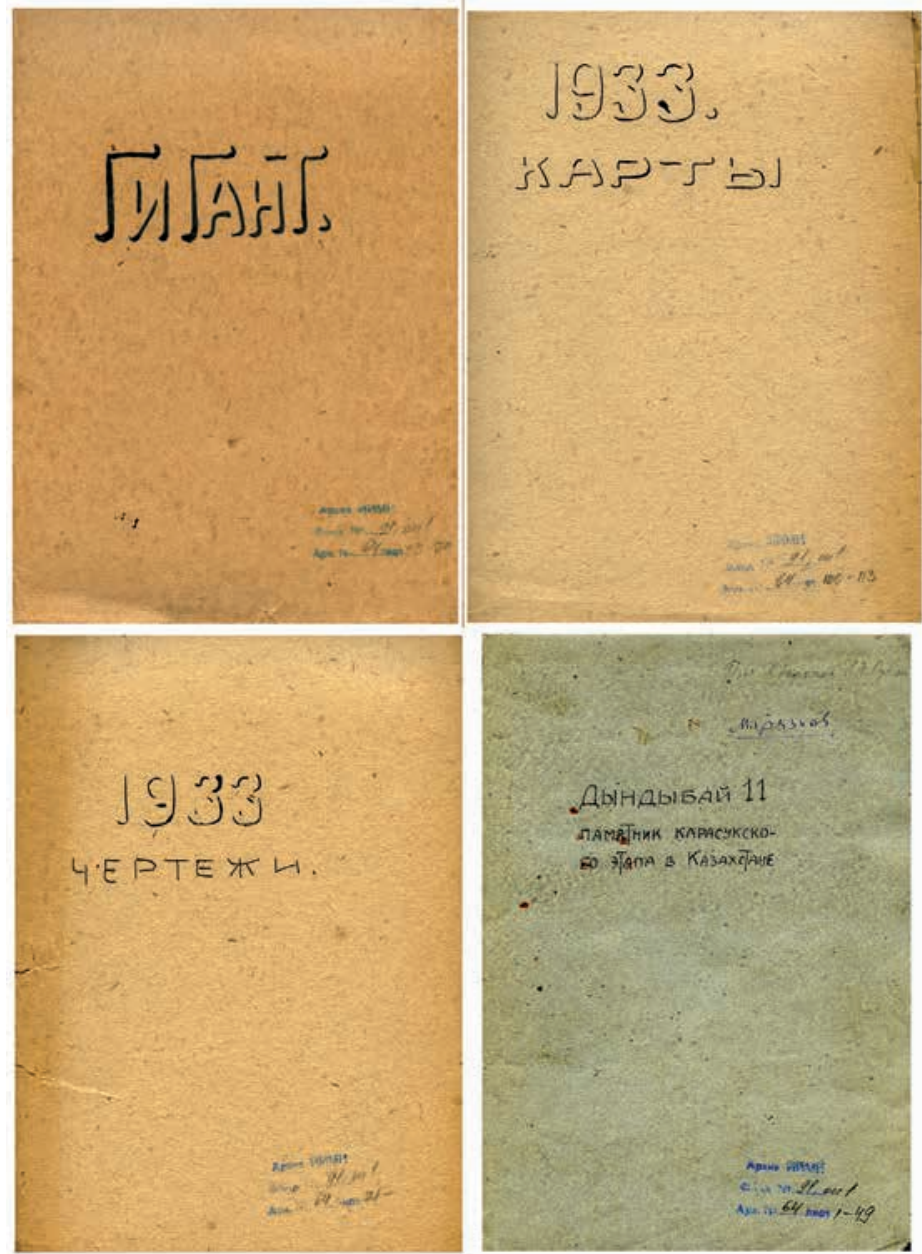

Рис. 14. Папки с подготовительными материалами к отчету о раскопках Нуринской экспедииии ГАИМК 1933 г. в архиве М. П. Грязнова (по: [Дандыбай 11 - памятник карасукской культуры..., л. 50-113])

Fig. 14. Folders with preparatory materials for the report on the excavations of the Nura expedition of GAIMK in 1933 in M. P. Gryaznov's archives (after: [In NA IIMK RAN, sheet 50-113])

поздняя из которых опубликована в 1946 г., из чего можно сделать вывод, что статья не могла быть закончена ранее этого времени. Рукопись несколько отличается от публикации, но в основном за счет изъятого в печатном варианте пространного введения, написанного в научнопопулярном стиле. На папке имеется любопытная карандашная пометка: «Для сборника И. А. Орбели». Она может свидетельствовать о том, что статья изначально готовилась М. П. Грязновым, после войны параллельно работавшим в Эрмитаже и ИИМК АН СССР, видимо, для какого-то несостоявшегося сборника к 60-летию академика И. А. Орбели, директора Государственного Эрми-

\section{Одна из папок архива} М. П. Грязнова, озаглавленная «Дындыбай 11 памятник карасукского этапа в Казахстане», содержит рукопись статьи, опубликованной в «Советской археологии» [Грязнов, 1952]. Текст явно писался уже после войны, так как автор ссылается на работы, самая тажа [Дандыбай 11 - памятник карасукской культуры..., л. 1-49]. Это объясняет сведения, приведенные С. С. Тихоновым, о том, что в 1946 г. М. П. Грязнов просил определить породы дерева, из которого были изготовлены некоторые предметы, найденные в кургане 11 [Тихонов, 2009, c. 192]. 
После выхода статьи в «Советской археологии» М.П. Грязнов уже не возвращался специально к этим материалам, видимо, закрыв для себя историю Нуринской экспедиции публикацией материалов Дандыбая.

\section{ЛИТЕРАТУРА}

1. Академическая археология на берегах Невы (от РАИМК до ИИМК РАН, 1919-2014 гг.) / Отв. ред.: Е.Н. Носов. СПб.: Дмитрий Буланин, 2013. 416 с.

2. Артамонов М.И., Грязнов М.П., Латынин Б.А. Инструкция по учету и охране памятников материальной культуры на новостройках / Отв. ред.: С.Н. Быковский. Л.: Изд-во ГАИМК, 1933. $16 \mathrm{c.}$ $286 \mathrm{c}$.

3. Ашнин Ф.Д., Алпатов В.М. «Дело славистов»: 30-е годы. М.: Наследие, 1994.

4. Бейсенов А.3., Варфоломеев В.В., Касеналин А.Е. Памятники бегазыдандыбаевской культуры Центрального Казахстана. Алматы: Институт археологии им. А.Х. Маргулана, 2014. 192 с.

5. Грязнов М.П Золото Восточного Казакстана и Алтая // Археологические работы Академии на новостройках в 1932-33 гг. / Отв. ред.: И.И. Мещанинов. Т. II. М.-Л.: ОГИЗ, 1935. С. 192-193 (ИГАИМК. Вып. 110).

6. Грязнов М.П. Памятники карасукского этапа в Центральном Казахстане // СА. 1952. Вып. XVI. С. 129-162.

7. Дандыбай 11 - памятник карасукской культуры в Казахстане. Памятник раннескифской эпохи в Казахстане (черновик отчета М.П. Грязнова [по] Нуринской [экспедиции] ГАИМК 1933 г.) // НА ИИМК РАН. РО, ф. 91, оп. 1, д. 64.

8. Докладная записка начальника археологической экспедиции о своей работе [c приложениями] // СПбФ АРАН, ф. 4, оп. 28, д. 19, л. 49-53.

9. Заявление административно-высланного Грязнова Михаила Петровича, проживающего в г. Вятке по Хлыновской улице дом 42 // Степи Евразии в древности и раннем средневековье: м-лы Междунар. научн. конф., посвящ. 100-летию со дня рожд. М.П. Грязнова / Отв. ред.: Ю.Ю. Пиотровский. СПб.: Изд-во Гос. Эрмитажа, 2002. Кн. I. C. 86.

10. И.В. Синицын. Черновые дневниковые заметки археологических раскопок в Калмыцкой области (колхоз им. Хомутникова в урочище «Три брата», с. Элиста и Нуринской экспедиции (Казахстан) в 1933 г. с рисунками погребений, находок и описью фотографий // НА ИИМК РАН. РО, ф. 2, оп. 1933 г., д. 300.

11. К 70-летию Ивана Васильевича Синицына // Античный мир и археология. Саратов: Изд-во Саратовского ун-та, 1972. Вып. 1. С. 5-11.

12. Каргин Ю.Ю. Полевые археологические исследования И.В. Синицына (К 110-летию со дня рождения) // Археология Восточно-Европейской степи / Отв. ред.: В.А. Лопатин. Саратов: ИЦ «Наука», 2010. Вып. 8. С. 7-29.

13. Кафедра истории России. История кафедры // Саратовский государственный университет. Исторический факультет. URL: https://www.sgu.ru/archive/ old.sgu.ru/files/ hist/vipusk19/history.html (дата обращения: 03.04.2020).

14. Кызласов И.Л. О Дорожном альбоме Л.Р. Кызласова 1948 года // Кызласов Л.Р. Дорожные зарисовки. Центрально-Казахстанская архитектурно-археологическая экспедиция Академии наук Казахской CCP. 18.VII-1.X.1948 года. Алматы: НИЦИА «Бегазы-Тамола», 2017. С. 11-16.

15. Кызласов Л.Р. Слово об Алеке́ Маргулане // Археологическое наследие Центрального Казахстана: изучение и сохранение. Сб. науч. ст., посвящ. 70-летию организации ЦКАЭ Академии наук Казахстана / Отв. ред.: А.З. Бейсенов, В.Г. Ломан. Алматы: НИЦИА «Бегазы-Тамола», 2017. Т. 1. С. 70-75. 
Смирнов Н.Ю. Неизвестный контекст знаменитого открытия: работа М.П. Грязнова...

16. Кызласов Л.Р., Маргулан А. Х. Плиточные ограды могильника Бегазы // КСИИМК. 1950. Вып. ХХХІІ. С. 126-136.

17. Бытовые фотографии родных и знакомых М.П. Грязнова // НА ИИМК РАН. РО, ф. 91, оп. 2, д. 41, л. 36.

18. Максимов Е.К. Павел Сергеевич Рыков (к 100-летию со дня рождения) // Археология восточно-европейской степи / Отв. ред.: В.Г. Миронов. Саратов: Изд-во Саратовского гос. ун-та, 1989. С. 3-11.

19. Максимов Е.К. Николай Константинович Арзютов // РА. 1998. № 2. С. 194-196.

20. Малов Н.М. Советская археология в Саратовском государственном университете (1918-1940): организационное становление, развитие и репрессии // Археология Восточно-Европейской степи. Саратов: Научная книга, 2006. Вып. 4. C. 4-28.

21. Маргулан А.Х. Отчет о работах Центрально-Казахстанской археологической экспедиции за 1947 г. // Известия АН КазССР. № 67. Сер. археол. 1949/1950. Вып. 2. C. 3-36.

22. Маргулан А.Х. Бегазы-дандыбаевская культура Центрального Казахстана. Алма-Ата: Наука, 1979. 360 с.

23. Материалы Нуринской экспедиции 1933 года. Отчёты. Полевые дневники и нивелировка // НА ИИМК РАН. РО, ф. 2, оп. 1933 г., д. 223.

24. Нуринская экспедиция ГАИМК - 1933 г. // НА ИИМК РАН. ФО, ф. 46, колл. № 407.

25. Отчеты и переписка о раскопках в Совхозе «Гигант» в Казакстане (район Караганды и р. Нура) // НА ИИМК РАН. РО, ф. 2, оп. 1933 г., д. 206.

26. Панкратова Е.Г. Археологические экспедиции 1930-х годов на территории ГУЛАГа (по материалам Санкт-Петербургского филиала Архива РАН) // У истоков советской археологии: организации и учреждения археологического профиля в новых реалиях: м-лы Междунар. научн. конф. / Отв. ред.: И.А. Сорокина. М.: Институт археологии РАН, 2019. С. 35-36.

27. Переписка Комитета новостроек об организации экспедиций на новостройках // НА ИИМК РАН. РО, Ф. 2, Оп. 1933 г., д. 74.

28. Переписка по организации работ и охране памятников древности и искусства в зонах строительства Управления лагерями ОГПУ «ГУЛАГ». 1933 г. // НА ИИМК РАН. РО, ф. 2, оп. 1933 г., д. 84.

29. Переписка с правительственными организациями по продовольственному и промтоварному снабжению учреждений ГУЛАГа // ГА РФ, ф. Р-9414, оп. 1, д. 1913.

30. Протоколы бюро Комитета по работам академии на новостройках и материалы к ним // НА ИИМК РАН. РО, ф. 2, оп. 1933 г., д. 75.

31. Рыков П.С. Нуринская экспедиция 1933 г. // ПИМК. 1933. № 9-10. С. 57-58.

32. Рыков Павел Сергеевич. Из Саратова в Ленинград. 3 письма, 2 конверта // НА ИИМК РАН. РО, ф. 91, оп. 3, д. 164.

33. Рыков П.С. Работы в совхозе «Гигант» (Караганда) // Археологические работы Академии на новостройках в 1932-33 гг. / Отв. ред.: И.И. Мещанинов. М.-Л.: ОГИЗ, 1935. Т. ІІ. С. 40-68 (ИГАИМК. Вып. 110).

34. Сводный квартальный обзор по производственной деятельности ИТЛ. 19311932 гг. // ГА РФ, ф. Р-9414, оп. 1, д. 2920.

35. Система исправительно-трудовых лагерей в СССР / Отв. ред. Н.Г. Охотин, А.Б. Рогинский. М.: Звенья, 1998. URL: http://old.memo.ru/history/nkvd/gulag/ (дата обращения: 15.05.2019).

36. Смирнов Н.Ю. Экспедиция профессора П.С. Рыкова в Центральный Казахстан в 1933 г. Причины и история организации // Маргулановские чтения - 2020: сб. м-лов междунар. науч.-практ. конф. «Великая Степь в свете археологических 
и междисциплинарных исследований». Алматы: Институт археологии им. А.Х. Маргулана, 2020. В печати.

37. Стенограмма пленума Комитета Государственной академии истории материальной культуры по работе на новостройках. 1934 г. // НА ИИМК РАН. РО, ф. 2, оп. 1934 г., д. 17.

38. Тихонов С.С. Могильник Дандыбай и его исследования Нуринской археологической экспедицией Института истории материальной культуры в 1933 году // Изучение историко-культурного наследия Центральной Евразии: сб. м-лов Междунар. научн. конф. «Маргулановские чтения - 2008». Караганда: Институт археологии им. А.Х. Маргулана, 2009. С. 187-193.

39. Тихонов С.С. История культуры Южной Сибири и Казахстана в материалах М.П. Грязнова // Андроновский мир / Отв. ред.: Н.П. Матвеева. Тюмень: Изд-во Тюменского гос. ун-та, 2010. С. 26-36.

40. Худяков М.Г. 25-летие научной деятельности проф. П.С. Рыкова // СЭ. 1935. № 2. C. $155-158$.

\section{Сведения об авторе:}

Смирнов Николай Юрьевич - кандидат исторических наук, старший научный сотрудник, Отдел археологии Центральной Азии и Кавказа, Институт истории материальной культуры РАН (г. Санкт-Петербург, Россия); kolaksais@yandex.ru

ТАНЫМАЛ АШЫЛЫМНЫҢ БЕЙМӘЛІМ МӘНМӘТІНІ: М. П. ГРЯЗНОВТЫН ОРТАЛЫҚ ҚАЗАҚСТАНДАҒЫ ПРОФЕССОР П. С. РЫКОВТЫН 1933 жЫЛҒЫ ЭКСПЕДИЦИЯСЫНЫН ҚҰРАМЫНДАҒЫ ЖҰМЫСЫ

(Беғазы-Дәндібай мәдениетінің алғашқы ескерткішінің ашылуына 85 жыл өтуіне орай)

\section{Н. Ю. Смирнов}

Мақалада құжаттық куәліктер негізінде М. П. Грязновтың Беғазы-Дәндібай мәдениетінің алғашқы ескерткіші - Орталық Қазақстандағы Дәндібай қорымындағы № 11 құрылысты ашуы мен зерттеу үдерісі қалпына келтіріледі. Алғаш рет М. П. Грязновтың МММТА Нұра экспедициясының жұмысына қатысуы, экспедиция жұмысының жағдайы және олардың ескерткішті ашқаннан кейінгі алғашқы ғылыми пайымдауына қатысты көптеген құжаттар ғылыми айналымға тартылған. Жарияланымды қазба жұмыстары кезіндегі экспедицияға қатысушылардың бірі түсірген әуесқой түсірілімдер мен экспедиция жұмысының барысына қатысты құжаттардың факсимилесі безендіре түседі.

Түйін сөздер: археология, М. П. Грязнов, М.Н. Комарова, Л. Р. Кызласов, А. Х. Марғұлан, П. С. Рыков, Беғазы-Дәндібай археологиялық мәдениеті, Қазақстан археологиясының тарихы, Қарағанды ЕТЛ, жаңа құрылыстардағы МММТА жұмысы жөніндегі комитет, МММТА Нұра экспедициясы, «Гигант» кеңшары, Орталық Қазақстан

\section{UNKNOWN CONTEXT OF THE FAMOUS DISCOVERY: M. P. GRYAZNOV'S WORK IN CENTRAL KAZAKHSTAN AS A PARTICIPANT OF PROF. P. S. RYKOV'S EXPEDITION IN 1933}

(to the recent 85th anniversary of the discovery of the first monument of the Begazy-Dandybay culture)

\section{N. Yu. Smirnov}

This paper, based on documentary evidence, reconstructs the history of the discovery and investigation of the first monument of the Begazy-Dandybay culture - structure no. 11 
Смирнов Н.Ю. Неизвестный контекст знаменитого открытия: работа М.П. Грязнова...

at the cemetery of Dandybay by M. P. Gryaznov in Central Kazakhstan. An entire series of archive documents concerned with the causes of M. P. Gryaznov's participation in the Nura expedition of the State Academy of the History of Material Culture (GAIMK), the conditions in which the expedition itself was working and the first attempt made by Gryaznov at the scientific interpretation of the site discovered by him are here first published. The publication is illustrated by amateur photos of the working moments taken during the excavations by one of the scientific workers of the expedition and facsimiles of the documents related with the expedition works.

Keywords: archaeology, M. P. Gryaznov, M. N. Komarova, L. R. Kyzlasov, A. Kh. Margulan, P. S. Rykov, Begazy-Dandybay archaeological culture, history of the archaeology of Kazakhstan, Karaganda ITL (Penitentiary Labour Camp), Committee for Activities of GAIMK at Construction Works, Nura expedition of GAIMK, Sovkhoz "Gigant", Central Kazakhstan

\section{REFERENCES}

1. Nosov, E. N. (Ed.). 2013. Akademicheskaya arheologiya na beregah Nevy (ot RAIMK do IIMK RAN, 1919-2014 gg.) (Academic archeology on the Neva (from the Russian Academy for the History of Material Culture to the Institute for the History of Material Culture of Russian Academy of Sciences, 1919-2014)). Saint Petersburg: "Dmitriy Bulanin" Publ. (in Russian).

2. Artamonov, M. I., Gryaznov, M. P., Latynin, B. A. 1933. Instrukciya po uchetu $i$ ohrane pamyatnikov materialnoy kultury na novostroykah (Instructions for the accounting and protection of monuments of material culture in new buildings) / Bykovskiy, S. N. (ed.). Leningrad: Gosudarstvennaya Akademiya Istorii Materialnoy Kultury Publ. (in Russian).

3. Ashnin, F. D., Alpatov, V. M. 1994. "Delo slavistov»: 30-e gody ("The Case of the Slavists": the 30s.). Moscow: "Nasledie" Publ. (in Russian).

4. Beisenov, A. Z., Varfolomeev, V. V., Kasenalin, A. E. 2014. Pamyatniki begazydandybaevskoy kultury Centralnogo Kazahstana (Monuments of the Begazy-Dandybay culture of Central Kazakhstan). Almaty: A. Kh. Margulan Institute of Archeology (in Russian).

5. Gryaznov, M. P. 1935. In Meshchaninov, I. I.(Ed.). Arheologicheskie raboty Akademii na novostrojkah v 1932-33 gg. (Archaeological work of the Academy on new buildings in 1932-33), II. Moscow-Leningrad: "Obiedinyonnoe Gosudarstvennoe Izdatelstvo" Publ., 192-193 (Proceedings of the State Russian Academy for the History of Material Culture. Vol. 110) (in Russian).

6. Gryaznov, M. P. 1952. In Sovetskaya arheologiya (Soviet archeology), XVI, 129162 (in Russian).

7. In NA IIMK RAN (Scientific archive of the Institute for the History of material culture of Russian Academy of Sciences). RO, f. 91, op. 1, d. 64 (in Russian).

8. In SPbF ARAN (St. Petersburg branch of the archive of the Russian Academy of Sciences), f. 4, op. 28, d. 19, 1. 49-53 (in Russian).

9. In Piotrovskiy, Yu. Yu. 2002. Stepi Evrazii v drevnosti i rannem srednevekovie (Eurasian Steppes of Antiquity and the Early Middle Ages), I. Saint Petersburg: State Hermitage Museum Publ., 86 (in Russian).

10. In NA IIMK RAN (Scientific archive of the Institute for the History of material culture of Russian Academy of Sciences). RO, f. 2, op. 1933 g., d. 300 (in Russian).

11. In Antichnyi mir i arheologiya (The Ancient World and Archeology). 1972. Saratov: Saratov State University Publ., 1, 5-11 (in Russian).

12. Kargin, Yu. Yu. 2010. In Lopatin, V. A. (Ed.). Arheologiya Vostochno-Evropeyskoy stepi (Archeology of the East European Steppe). Saratov: "Nauka" Publ, 8, 7-29 (in Russian). 
13. In Saratovskiy gosudarstvennyi universitet. Istoricheskiy fakultet (Saratov State University. History faculty). URL: https://www.sgu.ru/archive/ old.sgu.ru/files/hist/vipusk19/ history.html (data obrashcheniya: 03.04.2020) (in Russian).

14. Kyzlasov, I. L. 2017. In Kyzlasov L. R. Dorozhnye zarisovki. CentralnoKazahstanskaya arhitekturno-arheologicheskaya ekspediciya Akademii nauk Kazahskoy SSR. 18.VII-1.X.1948 goda (Road sketches. Central Kazakhstan Architectural and Archaeological Expedition of the Academy of Sciences of the Kazakh SSR. 18.VII - 1.X.1948). Almaty: "Begazy-Tamola" Publ., 11-16 (in Russian).

15. Kyzlasov, L. R. 2017. In Beisenov, A. Z., Loman, V. G. (Eds.). Arheologicheskoe nasledie Centralnogo Kazahstana: izuchenie i sohranenie (Archaeological Heritage of Central Kazakhstan: Study and Preservation), 1. Almaty: "Begazy-Tamola" Publ., 70-75 (in Russian).

16. Kyzlasov, L. R., Margulan, A. Kh. 1950. In KSIIMK (Brief Communications of the Institute of the History of Material Culture), XXXII, 126-136 (in Russian).

17. In NA IIMK RAN (Scientific archive of the Institute for the History of material culture of the Russian Academy of Sciences). RO, f. 91, op. 2, d. 41, 1. 36 (in Russian).

18. Maksimov, E. K. 1989. In Mironov, V. G. (Ed.). Arheologiya vostochno-evropeyskoy stepi (Archeology of the East European Steppe). Saratov: Saratov State University Publ., 3-11 (in Russian).

19. Maksimov, E. K. 1998. In Rossiyskaya arheologiya (Russian archaeology), 2, 194-196 (in Russian).

20. Malov, N. M. 2006. In Arheologiya Vostochno-Evropeyskoy stepi (Archeology of the East European Steppe). Saratov: "Nauchnaya kniga", 4, 4-28 (in Russian).

21. Margulan, A. Kh. 1949/1950. In Izvestiya AN KazSSR. Ser. arheol. (Bulletin of the Academy of Sciences of the Kazakh SSR. Ser. archaeol.), 67, vol. 2, 3-36 (in Russian).

22. Margulan, A. Kh. 1979. Begazy-dandybaevskaya kultura Centralnogo Kazahstana (Begazy-Dandybay culture of Central Kazakhstan). Alma-Ata: "Nauka" (in Russian).

23. In NA IIMK RAN (Scientific archive of the Institute for the History of material culture of the Russian Academy of Sciences). RO (Manuscript Department), f. 2, op. 1933 g., d. 223 (in Russian).

24. In NA IIMK RAN (Scientific archive of the Institute for the History of material culture of the Russian Academy of Sciences). FO (Photo Department), f. 46, koll. № 407 (in Russian).

25. In NA IIMK RAN (Scientific archive of the Institute for the History of material culture of the Russian Academy of Sciences). RO (Manuscript Department), f. 2, op. 1933 g., d. 206 (in Russian).

26. Pankratova, E. G. 2019. In Sorokina, I. A. (Ed.). U istokov sovetskoy arheologii: organizacii i uchrezhdeniya arheologicheskogo profilya $v$ novyh realiyah (At the origins of Soviet archeology: organizations and institutions of the archaeological profile in the new realities). Moscow: Institute of archeology RAS, 35-36 (in Russian).

27. In NA IIMK RAN (Scientific archive of the Institute for the History of material culture of the Russian Academy of Sciences). RO (Manuscript Department), F. 2, Op. 1933 g., d. 74 (in Russian).

28. In NA IIMK RAN (Scientific archive of the Institute for the History of material culture of the Russian Academy of Sciences). RO (Manuscript Department), f. 2, op. 1933 g., d. 84 (in Russian).

29. In GA RF (State archive of the Russian Federation), f. R-9414, op. 1, d. 1913 (in Russian).

30. In NA IIMK RAN (Scientific archive of the Institute for the History of material culture of the Russian Academy of Sciences). RO (Manuscript Department), f. 2, op. 1933 g., d. 75 (in Russian). 
Смирнов Н.Ю. Неизвестный контекст знаменитого открытия: работа М.П. Грязнова...

31. Rykov, P. S. 1933. In PIMK (Monuments of the history of material culture), 9-10, 57-58 (in Russian).

32. In NA IIMK RAN (Scientific archive of the Institute for the History of material culture of the Russian Academy of Sciences). RO (Manuscript Department), f. 91, op. 3, d. 164 (in Russian).

33. Rykov, P. S. 1935. In Meshchaninov, I. I. Arheologicheskie raboty Akademii na novostroykah v 1932-33 gg. (Archaeological work of the Academy on new buildings in 193233). Moscow-Leningrad: "Obiedinyonnoe Gosudarstvennoe Izdatelstvo" Publ., II, 40-68 (Proceedings of the State Russian Academy for the History of Material Culture. Vol. 110) (in Russian). Russian).

34. In GA RF (State archive of the Russian Federation), f. R-9414, op. 1, d. 2920 (in

35. Ohotin, N. G., Roginskiy, A. B. (Eds.). 1998. Sistema ispravitelno-trudovyh lagerey $v$ SSSR The system of forced labor camps in the USSR). Moscow: "Zveniya", URL: http://old.memo.ru/history/nkvd/gulag/ (in Russian).

36. Smirnov, N. Yu. 2020. In Baitanayev, B. A. (Ed.). Margulanovskie chteniya 2020 (Margulan readings - 2020). Almaty: A.Kh. Margulan Institute of Archeology. In print (in Russian).

37. In NA IIMK RAN (Scientific archive of the Institute for the History of material culture of the Russian Academy of Sciences). RO (Manuscript Department), f. 2, op. 1934 g., d. 17 (in Russian).

38. Tikhonov, S. S. 2009. In Margulanovskie chteniya - 2008 (Margulan readings 2008). Karaganda: A.Kh. Margulan Institute of Archeology, 187-193 (in Russian).

39. Tikhonov, S. S. 2010. In Matveeva, N. P. (Ed.). Andronovskiy mir (Andronovo world). Tyumen: Tyumen State University Publ., 26-36 (in Russian).

40. Khudyakov, M. G. 1935. In Sovetskaya etnografiya (Soviet ethnography), 2, 155158 (in Russian).

About the Author:

Smirnov Nikolay Yu. Candidate of historical sciences, senior researcher, Department of Archeology of Central Asia and the Caucasus, Institute for the History of Material Culture of the Russian Academy of Sciences, St. Petersburg, Russia; kolaksais@yandex.ru

Мүдделер қақтығысы туралы ақпаратты ашу. Автор мүдделер қақтығысының жоқтығын мәлімдейді.

/ Раскрытие информации о конфликте интересов. Автор заявляет об отсутствии конфликта интересов.

/ Disclosure of conflict of interest information. The author claim no conflict of interest.

Мақала туралы ақпарат / Информация о статье / Information about the article.

Редакцияға түсті / Поступила в редакцию / Entered the editorial office: 07.04.2020.

Рецензенттер мақұлдаған / Одобрено рецензентами / Approved by reviewers: 21.04.2020.

Жариялауға қабылданды / Принята к публикации / Accepted for publication: 05.05.2020. 